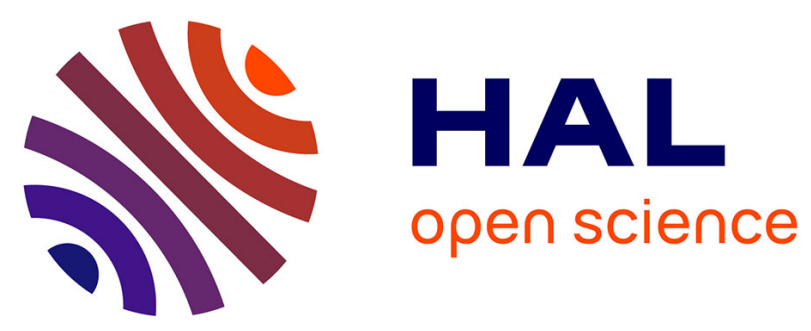

\title{
Acidic Properties of Alkaline-Earth Phosphates Determined by an Experimental-Theoretical Approach
}

E. Blanco, Q. Gu, J. Couble, L. Martin, T. Onfroy, G. Costentin, Jean-Francois Paul, Carine Michel, S. Loridant

\section{- To cite this version:}

E. Blanco, Q. Gu, J. Couble, L. Martin, T. Onfroy, et al.. Acidic Properties of Alkaline-Earth Phosphates Determined by an Experimental-Theoretical Approach. Journal of Physical Chemistry C, 2020, 124 (3), pp.2013-2023. 10.1021/acs.jpcc.9b10472 . hal-02472130

\section{HAL Id: hal-02472130 \\ https://hal.science/hal-02472130}

Submitted on 6 Nov 2020

HAL is a multi-disciplinary open access archive for the deposit and dissemination of scientific research documents, whether they are published or not. The documents may come from teaching and research institutions in France or abroad, or from public or private research centers.
L'archive ouverte pluridisciplinaire HAL, est destinée au dépôt et à la diffusion de documents scientifiques de niveau recherche, publiés ou non, émanant des établissements d'enseignement et de recherche français ou étrangers, des laboratoires publics ou privés. 
This document is confidential and is proprietary to the American Chemical Society and its authors. Do not copy or disclose without written permission. If you have received this item in error, notify the sender and delete all copies.

\section{Acidic Properties of Alkaline-earth Phosphates Determined by an Experimental-Theoretical Approach}

\begin{tabular}{|r|l|}
\hline Journal: & The Journal of Physical Chemistry \\
\hline Manuscript ID & jp-2019-10472y.R1 \\
\hline Manuscript Type: & Article \\
\hline Date Submitted by the \\
Author: & n/a \\
\hline Complete List of Authors: & $\begin{array}{l}\text { Blanco, Elodie; Institut de Recherches sur la Catalyse et I'Environnement } \\
\text { de Lyon } \\
\text { GU, Qingyi; Ecole normale superieure de Lyon } \\
\text { Couble, Julien; Institut de Recherches sur la Catalyse et l'Environnement } \\
\text { de Lyon } \\
\text { Martin, Lucile; Unité de Catalyse et Chimie du Solide } \\
\text { Onfroy, Thomas; UPMC, Laboratoire Systemes Interfaciaux Echelle } \\
\text { Nanometrique } \\
\text { Costentin, Guylene; UPMC, Lab. Réactivité de Surface } \\
\text { Paul, Jean-François; Unité de Catalyse et Chimie du Solide } \\
\text { Michel, Carine; Ecole normale superieure de Lyon, Laboratoire de Chimie } \\
\text { Loridant, Stephane; Institut de Recherches sur la Catalyse et } \\
\text { I'Environnement de Lyon }\end{array}$ \\
\hline
\end{tabular}

\section{SCHOLARONE ${ }^{\text {tw }}$ Manuscripts}




\title{
Acidic Properties of Alkaline-earth Phosphates Determined by an Experimental-Theoretical
}

\author{
Approach \\ Elodie Blanco ${ }^{a}$, Qingyi Gub, Julien Coublea, Lucile Martinc, Thomas Onfroyd, Guylène \\ Costentin ${ }^{d}$, Jean-François Paulc, Carine Michepp, , Stéphane Loridanta, ${ }^{*}$ \\ a Univ Lyon, Université Claude Bernard-Lyon 1, CNRS, IRCELYON-UMR 5256, 2 av. A. \\ Einstein, F-69626 Villeurbanne Cedex, France \\ b Univ Lyon, Ens de Lyon, CNRS UMR 5182, Université Claude Bernard Lyon 1, \\ Laboratoire de Chimie, F69342, Lyon, France \\ c Univ. Lille, CNRS, Centrale Lille, ENSCL, Univ. Artois, UMR 8181-UCCS Unité de \\ Catalyse et Chimie du Solide, F-59000 Lille, France
}


d Sorbonne Université, CNRS, Laboratoire Réactivité de Surface, LRSUPMC Univ Paris 06, UMR 7197, Laboratoire Réactivité de Surface, F-75005 Paris, France 
ABSTRACT. Alkaline-earth phosphates efficient in the dehydration of lactic acid to acrylic acid were previously shown to contain a surface mono/dihydrogen phosphate amorphous layer composed by $\mathrm{M}^{2+}$ cations, $\mathrm{P}=\mathrm{O}$ and $\mathrm{POH}$ groups. In this work, acidic properties of such a layer were determined combining FTIR spectra achieved at the dehydrated state and under water vapor and DFT simulations of non-defective and defective MPOH structure. The FTIR spectra of adsorbed pyridine and lutidine revealed the presence of moderate Lewis acid sites (LAS) and of $\mathrm{POH}$ groups interacting by $\mathrm{H}$-bonding without significant protonation. DFT calculations were key to interpret FTIR spectra after adsorption of $\mathrm{NH}_{3}$ : when solely adsorbed, $\mathrm{NH}_{3}$ interacts with the LAS on both the nondefective surface and the defective surface while the $\mathrm{POH}$ for which $\mathrm{H}$ points up towards the gas phase are reoriented downward. Brønsted acid sites (BAS) were shown to form under water vapor. This phenomenon was shown by DFT to arise from a more acidic character of $\mathrm{HPO}_{4}{ }^{2-}$ species for non-defective surface and casual formation of nondefective surface leading to higher amount of $\mathrm{H}_{2} \mathrm{PO}_{4}{ }^{-}$species, which are more acidic BAS. 


\section{INTRODUCTION}

Acrylic Acid (AA) is a platform molecule used as a building block to produce acrylate polymers and plastics and currently produced by catalytic oxidation of propylene in large volume (6 Mt/y predicted by 2020). ${ }^{1,2}$ From both environmental and economical point of view, alternative routes to produce acrylic acid should be developed. Glycerol is a potential renewable raw material to produce acrylic acid by oxidehydration. ${ }^{3}$ Yields higher than $50 \%$ were obtained on $\mathrm{W}-\mathrm{V}-\mathrm{Nb}$ mixed oxides with hexagonal tungsten bronze structure. ${ }^{4,5}$

Another investigated route is the dehydration of Lactic Acid (LA), a platform molecule used to produce chemical commodities and PLA polymers. ${ }^{1,2,6}$ Lactic acid is currently yielded by carbohydrates fermentation ${ }^{1,2,6}$ but can also be obtained by alternative fermentation processes using various substrates ${ }^{7,8}$ and by glycerol catalytic dehydrogenation. ${ }^{9}$ The global market for lactic acid was $0.75 \mathrm{Mt} / \mathrm{y}$ in 2017 and is projected to reach $1.8 \mathrm{Mt} / \mathrm{y}$ by $2022 .{ }^{10}$ Modified zeolites, sulphates/nitrates, and phosphates were specifically investigated. The best yields were obtained using alkaline earth metal phosphates (up to $85 \%$ AA yield) which furthermore are more stable than zeolites. ${ }^{1,2,6}$

We established correlations between the $\mathrm{NH}_{3}$ and $\mathrm{CO}_{2}$-TPD curves and the AA selectivity using alkaline earth phosphates as catalysts. ${ }^{11}$ The catalysts with only weak acid and basic sites were selective and their $\mathrm{NH}_{3}$ and $\mathrm{CO}_{2}$-TPD curves were surprisingly quite similar. Furthermore, the best AA selectivity was obtained for barium orthophosphate, for which the acid to base balance was close to 1. It suggested the participation of acid-base pairs in the mechanism. However, TPD measurements were achieved after pre-treatment at the calcination temperature while water vapor was present in the reaction feed and generated by dehydration. More recently, characterization of the prepared alkaline earth phosphates (including barium orthophosphate) showed the systematic 
presence of a surface mono/dihydrogen phosphate amorphous (non-crystalline for X-rays and electron diffraction) layer containing POH species. ${ }^{12}$ In situ DRIFT measurements have suggested that formation of $\mathrm{POH}$ groups was favored under water vapor and that these species interacted with reactants or reaction products at the reaction temperature.

DFT calculations could help in rationalizing the experimental observations. For instance, Paul and co-workers investigated the LA to AA transformation but on $\mathrm{ZrO}_{2} \cdot{ }^{13}$ They identified that on this oxide, the dehydration site is clearly an acido-basic pair, where the acid site $\mathrm{Zr}^{4+}$ stabilizes the leaving $\alpha-\mathrm{OH}$ and the basic $\mathrm{O}^{2-}$ site on zirconia plays the role of proton acceptor. Theoretical studies were also achieved on alkaline earth phosphates but mostly on hydroxyapatites $\mathrm{Ca}_{5}\left(\mathrm{PO}_{4}\right)_{3}(\mathrm{OH})$ due to their important using in biomaterials. ${ }^{14}$

In the present work, acidic sites of alkaline-earth phosphates catalysts were characterized by $\mathrm{NH}_{3}$ adsorption followed by IR spectroscopy at the dehydrated state and in the presence of water vapor. The IR spectra were assigned from DFT calculations, which also explained acidic properties determined by $\mathrm{NH}_{3}$ adsorption. Characterization of acidity was strengthened by adsorption of pyridine and lutidine followed by IR spectroscopy.

\section{METHODS}

\subsection{Catalysts preparation}

Barium orthophosphate (labelled $\mathrm{BaOP}$ ) was prepared by mixing a solution of diammonium hydrogen phosphate $\left(\mathrm{NH}_{4}\right)_{2} \mathrm{HPO}_{4}\left(\right.$ Aldrich, $99 \%$ ) at 0.20 mol. $\mathrm{L}^{-1}$ for which the $\mathrm{pH}$ was previously adjusted to 9 adding $\mathrm{NH}_{4} \mathrm{OH}(32 \% \mathrm{vol})$ and a solution of barium nitrate $\left(\mathrm{Ba}\left(\mathrm{NO}_{3}\right)_{2}\right)$ (Aldrich, $>99 \%$ ) at $0.30 \mathrm{~mol} \cdot \mathrm{L}^{-1}$. The latter one was added drop wise while maintaining constant the $\mathrm{pH}$ and stirring for $1 \mathrm{~h}$. The precipitate was filtrated off, washed with deionized water, dried at $100{ }^{\circ} \mathrm{C}$ and 
crushed before calcination under air flow at $600{ }^{\circ} \mathrm{C}$ for $6 \mathrm{~h}$.

\subsection{Catalysts characterizations}

Analysis of the acidic properties of samples was performed by adsorption-desorption of pyridine and lutidine followed by infrared spectroscopy. Self-supported wafers were placed inside the IR cell and then outgassed under secondary vacuum at $350{ }^{\circ} \mathrm{C}$ for $2 \mathrm{~h}$. In the following, the samples were contacted at room temperature with gaseous basic probe via a separate cell containing liquid pyridine or lutidine. The spectra were then recorded following desorption at increasing temperature with a Bruker Vector 22 spectrometer (resolution $2 \mathrm{~cm}^{-1}, 64$ scans). The reported spectra were obtained after subtraction of the spectrum recorded before probe adsorption.

In situ DRIFT spectra were achieved with a Nicolet 6700 FTIR spectrometer (Thermo Scientific) equipped with Praying Mantis ${ }^{\text {TM }}$ High Temperature Reaction Chamber (Harrick, model HVC-DRP-4). The $\mathrm{CaF}_{2}$ windows used for the experiments were heated at $70-80{ }^{\circ} \mathrm{C}$ with external water system to avoid condensation. The effect of water was investigated by flowing $30 \% \mathrm{H}_{2} \mathrm{O}-\mathrm{He}$ or $30 \% \mathrm{D}_{2} \mathrm{O}-\mathrm{He}$ at $380{ }^{\circ} \mathrm{C}$ after pre-treatment at $380{ }^{\circ} \mathrm{C}$ for $30 \mathrm{~min}$ under He. Such high water partial pressure was obtained using a saturator heated at $70{ }^{\circ} \mathrm{C}$. The background corresponded to the spectrum of dehydrated $\mathrm{KBr}$.

In situ FTIR acidity measurements were performed on self-supported pellets $(53 \mathrm{mg})$ with a Nicolet 6700 spectrometer (ThermoScientific) using a homemade stainless steel IR cell reactor specially designed to limit the gas phase contribution (its optical path is $2.2 \mathrm{~mm}$ ) ${ }^{15}$ and $\mathrm{NH}_{3}$ as probe molecule. This IR cell allowed the study of adsorbed species in the range $20-450{ }^{\circ} \mathrm{C}$ under gas flow rates (200 mL.min ${ }^{-1}$ in the present study) of gas mixtures at atmospheric pressure such as $\mathrm{x} \% \mathrm{NH}_{3} / \mathrm{y} \% \mathrm{H}_{2} \mathrm{O} / \mathrm{He}$ with $\mathrm{x}$ and $\mathrm{y}$ in the ranges $0-1 \%$ and $0-3 \%$ respectively. The amount of $\mathrm{H}_{2} \mathrm{O}$ 
was controlled using a saturator/condenser system as described previously. ${ }^{16} \mathrm{BaOP}$ pellet was pretreated at $380{ }^{\circ} \mathrm{C}$ under $20 \% \mathrm{O}_{2}-\mathrm{He}$ for $1 \mathrm{~h}$ and then $\mathrm{He} . \mathrm{NH}_{3}$ adsorption equilibrium was followed at $2 \% \mathrm{NH}_{3}$ upon heating and cooling between RT to $200{ }^{\circ} \mathrm{C}$. The AEIR (Adsorption Equilibrium InfraRed spectroscopy) method was used to determine individual $\mathrm{NH}_{3}$ heats of adsorption from the evolution of the IR band area of each adsorbed $X_{a d s}$ species with the increase in $T_{a}$ in isobaric conditions. The experimental curve $\theta \mathrm{X}_{\exp }=\mathrm{f}\left(\mathrm{T}_{\mathrm{a}}\right)$, with $\theta$ corresponding to the coverage of sites, was compared to the one obtained from the Temkin model assuming localized adsorbed species. Adjustment of the theoretical curve to the experimental data provides $E_{x}(1)$ and $E_{x}(0)$, the heats of adsorption at high and low coverages of the $X_{\text {ads }}$ species, respectively. The accuracy of the method to determine $\mathrm{NH}_{3}$ heats of adsorption has been evidenced for $\mathrm{TiO}_{2}$ support and $\mathrm{V}_{2} \mathrm{O}_{5} / \mathrm{WO}_{3} / \mathrm{TiO}_{2}$ catalysts. ${ }^{17-19}$ Acidity measurements in presence of water vapor ${ }^{20}$ were achieved at adsorption equilibrium flowing $1 \% \mathrm{NH}_{3}-3 \% \mathrm{H}_{2} \mathrm{O}-\mathrm{He}$ mixture upon heating and cooling between RT and 200 ${ }^{\circ} \mathrm{C}$.

\subsection{DFT Computational details}

Density functional theory (DFT) calculations were carried out using the Vienna ab initio simulation package (VASP). ${ }^{21-23}$ The exchange and correlation terms were obtained by the Perdew-Burke-Ernzerhof form of Generalized Gradient Approximation (GGA-PBE) functional. ${ }^{24}$ The core electrons were kept frozen and a projector-augmented wave (PAW) method was used to substitute the core electrons. ${ }^{25} \mathrm{~A}$ cut-off energy of $550 \mathrm{eV}$ of the plane wave basis set was used to describe the valence electrons. The bulk optimization would reach the convergence when the energy was converged to $1 \times 10^{-6} \mathrm{eV}$ and the forces were smaller than $0.01 \mathrm{eV} / \AA$ with a k-point mesh of $5 \times 2 \times 5$. For optimization of the slab, the same energy convergence criterion was used and 
the convergence criterium on the forces was set to $0.03 \mathrm{eV} / \AA$. The k-point mesh was adapted to the super cell size using a mesh of $5 \times 5 \times 1$ k-points. Frequencies were computed within the harmonic approximation. Gibbs free energies were derived using those frequencies, and for the molecules using the perfect gas and rigid rotator approximations.

Based on the previous characterizations of the $\mathrm{BaOP}$ catalyst $\mathrm{t}^{11,12}$ and on the fact that $\mathrm{Ca}$ and $\mathrm{Ba}$ are expected to have similar properties being both alkaline-earth elements, we selected the Brushite, a well-known layered calcium hydrogen orthophosphate dihydrate, ${ }^{26-28}$ to model the amorphous layer lying over the catalyst crystallites. In solution, Brushite forms thin hexagonal platelet. ${ }^{27,29}$ Since the (010) surface corresponds to the basal plane of the platelets, it is expected to be the most stable and have a very low surface energy. In order to define a model of this surface, the cutting plane was located in the middle of the gap between two layers. The number of water molecule was kept equal to the number in the solid. Using this choice, the surface is created cutting only hydrogen bonds. Two other planes perpendicular to the basal plane were studied: the (100) and the (001) in order to model the edges of the platelets. The two surfaces have been defined without breaking any $\mathrm{P}-\mathrm{O}$ or $\mathrm{O}-\mathrm{H}$ bonds, in order to reduce their surface energies. For the three surfaces, symmetric and stoichiometric slabs were used with a vacuum layer of $15.14 \AA$ to avoid the interaction between the slabs. The computed surface energies for (001), (010) and (100) were $0.047 \mathrm{eV} / \AA^{2}, 0.016 \mathrm{eV} / \AA^{2}$ and $0.032 \mathrm{eV} / \AA^{2}$ respectively, confirming the greater stability of the (010) surface.

The adsorption of the molecules was performed on the top of the most favorable surface (010) surface using a $\mathrm{p}(2 \times 2)$ asymmetric slab made of $16 \mathrm{CaHPO}_{4} \cdot 2 \mathrm{H}_{2} \mathrm{O}$, where the top surface layers, including $8 \mathrm{CaHPO}_{4} \cdot 2 \mathrm{H}_{2} \mathrm{O}$, were allowed to relax while the bottom $8 \mathrm{CaHPO}_{4} \cdot 2 \mathrm{H}_{2} \mathrm{O}$ were constrained during the geometry optimization. 
The IR spectroscopy was modelled by accurately determining the vibrational spectrum of a system. We used the density functional perturbation theory in our study to determine the Hessian matrix, and finally obtain the wavenumber of every vibration mode. ${ }^{30}$ Within this framework, the overtones are not simulated and the influence of the temperature on the vibration wavenumbers is not included. We determined the scaling factor between experimental wavenumbers and DFT ones using $\mathrm{NH}_{3}$ and $\mathrm{H}_{2} \mathrm{O}$ as a reference and we obtained 0.98 for the stretching vibration modes and 1.00 the for bending ones as shown in Table S1 of Supplementary material. Scaling down some wavenumbers to improve the quality of the prediction obtained within the harmonic approximation allows us to partially recover anharmonicity effects. ${ }^{31-33}$ The good agreement with the experimental spectra confirms that this factor established on gas phase spectra of water and ammonia is still valid for adsorbed species.

\section{RESULTS}

\subsection{Characterization of the dehydrated and hydrated state}

The main structural and textural properties of BaOP catalyst have been previously described. ${ }^{11}$ Shortly, it contained mostly crystalline $\mathrm{Ba}_{3}\left(\mathrm{PO}_{4}\right)_{2}$ and its specific surface area was $8.9 \mathrm{~m}^{2} \cdot \mathrm{g}^{-1}$. Chemical and XPS analyses showed sub-stoichiometric Ba/P ratios (1.38 and 1.28, respectively instead of 1.5 for stoichiometric $\left.\mathrm{Ba}_{3}\left(\mathrm{PO}_{4}\right)_{2}\right)$ that could be ascribed to the presence of either small amount of crystalline $\alpha-\mathrm{Ba}_{2} \mathrm{P}_{2} \mathrm{O}_{7}{ }^{11}$ and a phosphorus rich amorphous (non-crystalline) phase which does not diffract either by X-rays and electron diffractions. The latter phase was shown to correspond to a surface layer containing $\mathrm{POH}$ species and lying over $\mathrm{Ba}_{3}\left(\mathrm{PO}_{4}\right)_{2}$ crystallites. ${ }^{12}$ It could be either a stoichiometric $\mathrm{BaHPO}_{4}$ or a mixture of mono and dihydrogen phosphate with a general formula $\mathrm{Ba}_{(1-\mathrm{x})}\left(\mathrm{HPO}_{4}\right)_{1-2 \mathrm{x}}\left(\mathrm{H}_{2} \mathrm{PO}_{4}\right)_{2 \mathrm{x}}$. 
A DRIFT spectrum of $\mathrm{BaOP}$ treated under helium flow at $380^{\circ} \mathrm{C}$ is plotted in Figure 1 . The bands between 1850 and $2050 \mathrm{~cm}^{-1}$ corresponded to overtones of $v(\mathrm{P}=\mathrm{O})$ vibrations which are located around $1000 \mathrm{~cm}^{-1} .{ }^{34}$ The band at $3660 \mathrm{~cm}^{-1}$ was ascribed to $\mathrm{v}(\mathrm{PO}-\mathrm{H})$ stretching vibrations of free surface species by analogy with deficient hydroxyapatites. ${ }^{12}$ The broad band located around $3190 \mathrm{~cm}^{-1}$ corresponded to $v(\mathrm{PO}-\mathrm{H})$ stretching vibrations as observed for alkaline earth hydrogen phosphates. ${ }^{35-38}$ This large difference of wavenumber could arise from the effect of hydrogen bonds in bulk hydrogen phosphates leading to weakening of PO-H bonds and stretching vibrations at lower wavenumbers.

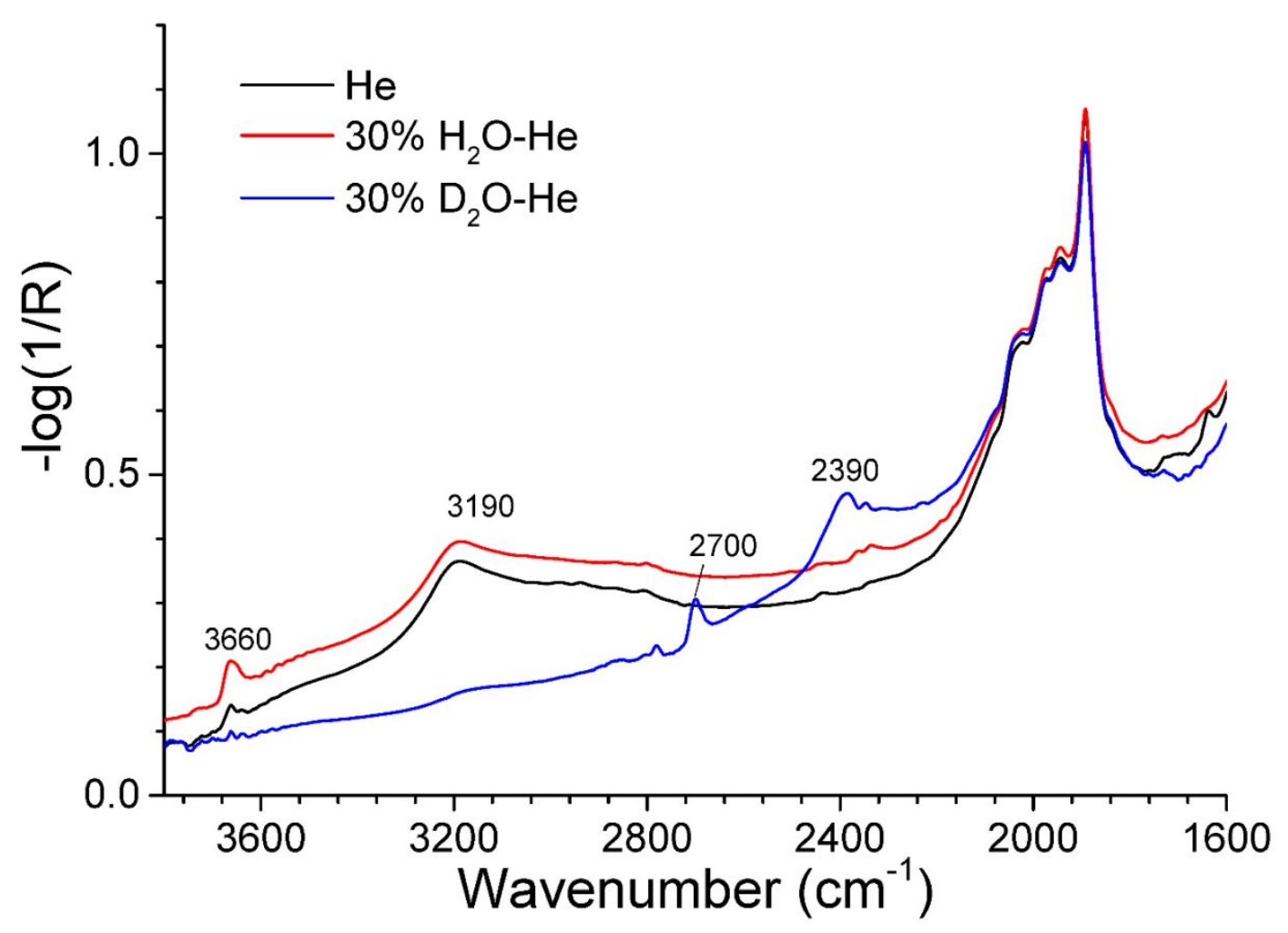

Figure 1. In situ DRIFT spectra of $\mathrm{BaOP}$ at $380{ }^{\circ} \mathrm{C}$ under $\mathrm{He}, 30 \% \mathrm{H}_{2} \mathrm{O}-\mathrm{He}$ and $30 \% \mathrm{D}_{2} \mathrm{O}-\mathrm{He}$. The background corresponds to the spectrum of dehydrated $\mathrm{KBr}$ (the $\mathrm{R}$ reflectance is equal to $\mathrm{I} / \mathrm{I}_{\mathrm{KBr}}$ ).

The DRIFT spectrum recorded under $30 \% \mathrm{H}_{2} \mathrm{O}-\mathrm{He}$ flow at the same temperature was similar. 
However, the absorbance of the $\mathrm{v}(\mathrm{PO}-\mathrm{H})$ band at $3660 \mathrm{~cm}^{-1}$ was increased evidencing formation of additional POH species. This phenomenon could arise from hydrolysis of the weak amount of $\alpha-\mathrm{Ba}_{2} \mathrm{P}_{2} \mathrm{O}_{7}$ leading to $\mathrm{BaHPO}_{4}$. Note that the $\delta$ bending mode of chemisorbed $\mathrm{H}_{2} \mathrm{O}$ at $1600-1630$ $\mathrm{cm}^{-1} 39,40$ was not observed showing such species was not present at the surface of BaOP sample. Isotopic labelling achieved under $30 \% \mathrm{D}_{2} \mathrm{O}-\mathrm{He}$ at $380{ }^{\circ} \mathrm{C}$ led to a shift of the bands at 3660 and $3190 \mathrm{~cm}^{-1}$ to 2700 and $2390 \mathrm{~cm}^{-1}$, respectively while the framework vibrational bands at 1850 $2050 \mathrm{~cm}^{-1}$ remained unchanged. These shifts are close to the ones expected for deuteration of $\mathrm{OH}$ groups considering harmonic oscillator (ratios of 0.74 and 0.75 , respectively instead of 0.73 ).

\subsection{Modelling of the surfaces and influence of the water amount}

The Brushite structure was built based on the neutron single crystal diffraction study ${ }^{26}$ with a composition of $4 \mathrm{CaHPO}_{4} \cdot 2 \mathrm{H}_{2} \mathrm{O}$ and a C-centered monoclinic cell within the space group Cc $\left(\# 9, \mathrm{C}_{\mathrm{s}}{ }^{4}\right)$, as shown in Figure 2.

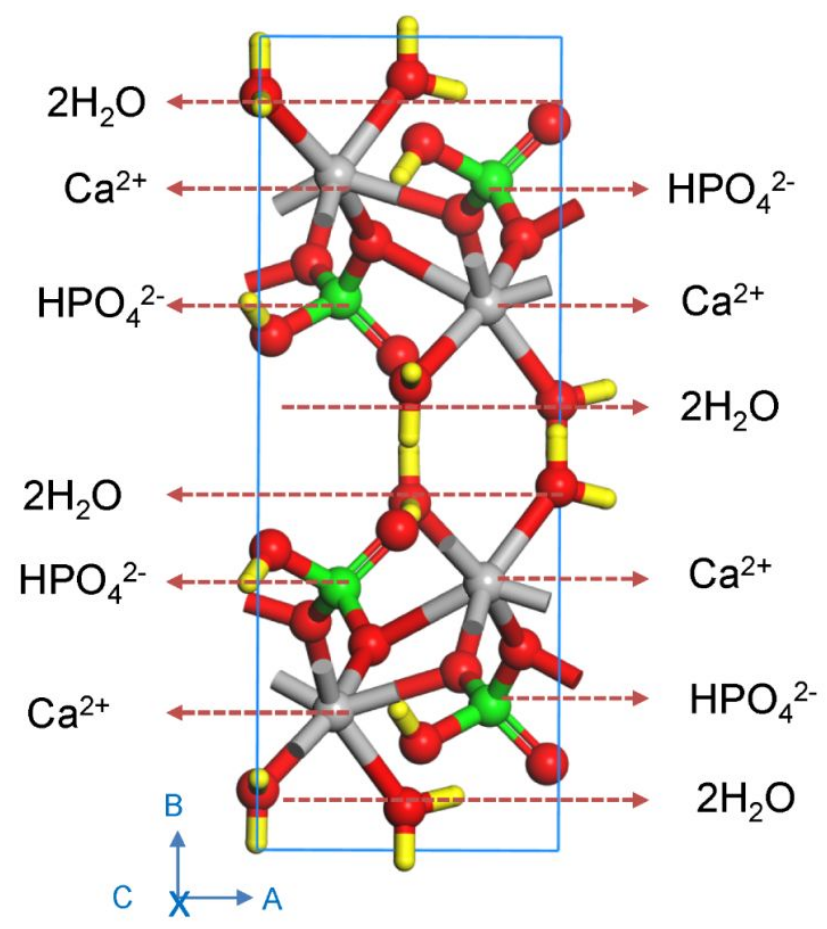


Figure 2. Unit cell of the layered structure of the Brushite, containing $\mathrm{Ca}$ atoms (grey), $\mathrm{O}$ atoms (red), $\mathrm{H}$ atoms (yellow) and $\mathrm{P}$ atoms (green).

The calculated cell parameters of $\mathrm{a}=5.98 \AA, \mathrm{b}=15.14 \AA$ and $\mathrm{c}=6.24 \AA$, are in good agreement with the experimental ones $\left(a_{\exp }=5.80 \AA, b_{\exp }=15.13 \AA, c_{\exp }=6.32 \AA\right) .{ }^{26} \mathrm{~A}$ detailed description of the brushite structure can be found in the Hirsch's work. ${ }^{27}$

The (010) surface of Brushite is the most stable surface computed (see computational details). As shown in Figure 3, the top of this surface is covered with eight water molecules per unit cell. We will consider later this as a complete monolayer of water, $\theta\left(\mathrm{H}_{2} \mathrm{O}\right)=1 \mathrm{ML}$. One can distinguish two orientations: (i) water marked $\mathrm{W}_{\mathrm{a}}$ is perpendicular to the surface, $2.55 \AA$ far away from the nearest $\mathrm{Ca}^{2+}$ atom, and gives a $\mathrm{H}$ bond to the $\mathrm{O}$ of $\mathrm{HPO}_{4}{ }^{2-}$ and accepts an $\mathrm{H}$ bond from another water molecule nearby (ii) the other water, $\mathrm{W}_{\mathrm{b}}$, is parallel to the surface, closer to $\mathrm{Ca}^{2+}$ with a distance of $2.47 \AA$ and is also involved in a $\mathrm{H}$ bond network, donating to $\mathrm{HPO}_{4}{ }^{2-}$ and to $\mathrm{W}_{\mathrm{a}}$.

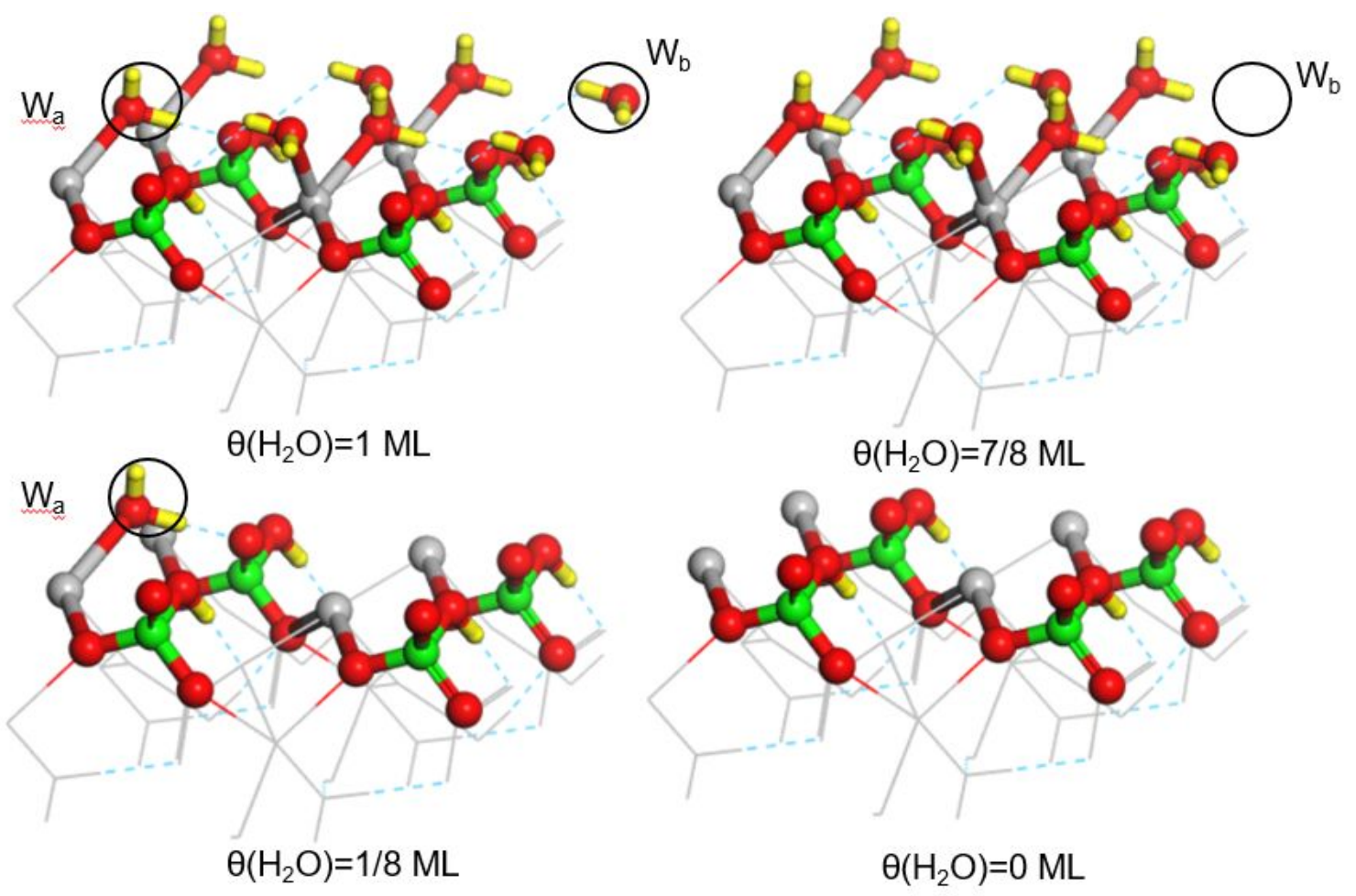


Figure 3. Structures of the (010) surface of $\mathrm{CaHPO}_{4} \cdot \mathrm{nH}_{2} \mathrm{O}$ with different water coverages, $\theta\left(\mathrm{H}_{2} \mathrm{O}\right)=1 \mathrm{ML}, 7 / 8$ ML, 1/8 ML and $0 \mathrm{ML}$. Only half of the surface structure is shown here for simplicity. The two different types of water molecules are marked as $\mathrm{W}_{\mathrm{a}}$ and $\mathrm{W}_{\mathrm{b}}$ highlighted by a black circle in the top left structure, which corresponds to the structure obtained as cleaved from the bulk. The $\mathrm{H}$ bond network of $\mathrm{W}_{\mathrm{a}}$ and $\mathrm{W}_{\mathrm{b}}$ is shown in light blue dashed lines. At $1 \mathrm{ML}, 8$ water molecules are found. At $7 / 8 \mathrm{ML}$, one $\mathrm{W}_{\mathrm{b}}$ water has been removed and the black circle indicates its former position. At 1/8ML, only one water molecule remains ( $\mathrm{W}_{\mathrm{a}}$ type) as highlighted by a black circle. Color-coding: grey for calcium, red for oxygen, green for phosphorus and yellow for hydrogen.

This highly hydrated surface can be easily dehydrated raising the temperature. The fully hydrated surface as cleaved from the bulk structure has a water coverage of $\theta\left(\mathrm{H}_{2} \mathrm{O}\right)=1 \mathrm{ML}$, which corresponds to eight water molecules per unit cell. We considered various coverages in water, $\theta\left(\mathrm{H}_{2} \mathrm{O}\right)=1 \mathrm{ML}, 7 / 8 \mathrm{ML}, 1 / 8 \mathrm{ML}$ and $0 \mathrm{ML}$, as shown in Figure 3. To start, we generated a structure with a lower coverage of $\theta\left(\mathrm{H}_{2} \mathrm{O}\right)=7 / 8 \mathrm{ML}$ removing one water molecule. The structure with $\mathrm{W}_{\mathrm{b}}$ deleted is $-20 \mathrm{~kJ} \cdot \mathrm{mol}^{-1}$ more stable than the one where $\mathrm{W}_{\mathrm{a}}$ is deleted, thus only the surface with $\mathrm{W}_{\mathrm{b}}$ deleted is shown in Figure 3. Next, we built a weakly hydrated surface, keeping only one water $\left(\mathrm{W}_{\mathrm{a}}\right)$, reaching a coverage of $\theta\left(\mathrm{H}_{2} \mathrm{O}\right)=1 / 8 \mathrm{ML}$. Finally, a fully dehydrated surface was also computed $\left(\theta\left(\mathrm{H}_{2} \mathrm{O}\right)=0 \mathrm{ML}\right)$, where the eight water molecules exposed at the external surface were deleted but the ones inside and in the bottom layers were still preserved. The relative stability of these surfaces as function of the temperature under 1 atm pressure of water is shown in Figure 4. 


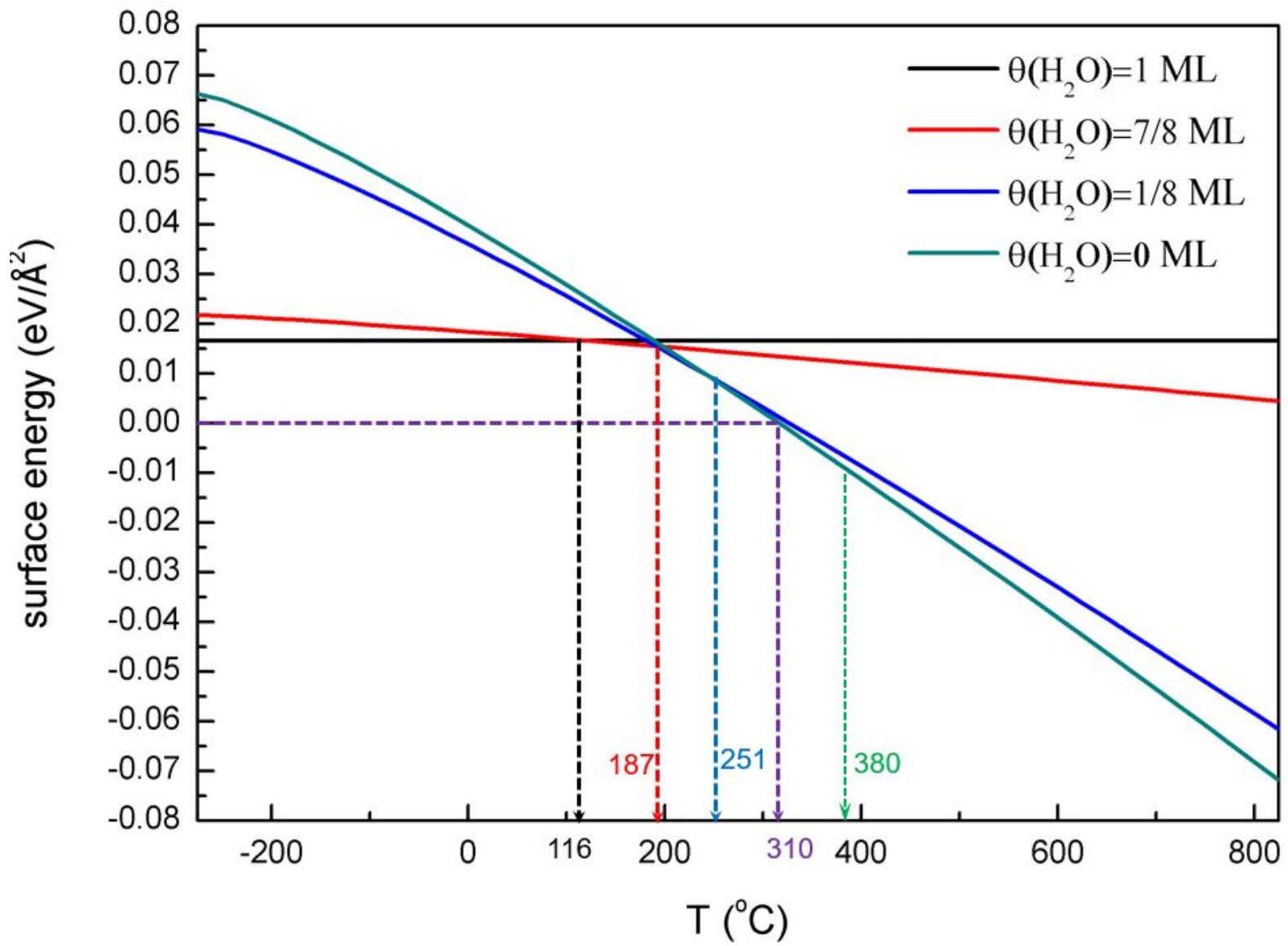

Figure 4. Surface energy in $\mathrm{eV} / \AA^{2}$ of Brushite (010) surfaces with various coverages $\left(\theta\left(\mathrm{H}_{2} \mathrm{O}\right)=1 \mathrm{ML}, 7 / 8 \mathrm{ML}, 1 / 8 \mathrm{ML}\right.$ and $0 \mathrm{ML}$ ) in water as function of the temperature and under a pressure in water of $1 \mathrm{~atm}$.

When the temperature is lower than $116^{\circ} \mathrm{C}$, the surface prefers to be covered with water. At $116^{\circ} \mathrm{C}$, the surface starts to dehydrate, one $\mathrm{W}_{\mathrm{b}}$ is desorbed and the exposed surface has a coverage of $\theta\left(\mathrm{H}_{2} \mathrm{O}\right)=7 / 8 \mathrm{ML}$. This temperature threshold for dehydration is consistent with the experimental one $\left(80{ }^{\circ} \mathrm{C}\right)$ found by Dosen et al. ${ }^{41}$ With an increase in the temperature, the dehydration keeps proceeding and at $187^{\circ} \mathrm{C}$, a coverage of $\theta\left(\mathrm{H}_{2} \mathrm{O}\right)=1 / 8 \mathrm{ML}$ is reached and when the temperature is higher than $251{ }^{\circ} \mathrm{C}$, the surface is totally dehydrated. It should also be noted that the surface energy becomes negative when the temperature is higher than $310^{\circ} \mathrm{C}$, which means that a dehydration of the bulk should occur. Such transformation to $\mathrm{CaHPO}_{4}$ (Monetite) ${ }^{14}$ was not further investigated 
since the purpose was to build a model of the exposed facet of the BaOP catalyst. However, these temperatures of complete dehydration of the surface and of likely bulk dehydration are consistent with experimental observations where the transformation to Monetite is complete between 200 and $220^{\circ} \mathrm{C} .{ }^{41}$ Based on the above discussion, it is clear that at the reaction temperature of $380{ }^{\circ} \mathrm{C}$ (which is also the IR spectrum recording temperature), the most favorable surface is the dehydrated surface. For experiments performed under $30 \% \mathrm{H}_{2} \mathrm{O}-\mathrm{He}$, we will include one water molecule to probe the impact of the modifications induced by the change of atmosphere and consider the $\theta\left(\mathrm{H}_{2} \mathrm{O}\right)=1 / 8 \mathrm{ML}$ coverage.

As the amorphous layer lying over $\mathrm{Ba}_{3}\left(\mathrm{PO}_{4}\right)_{2}$ crystallites of the $\mathrm{BaOP}$ catalyst could be a phase with a general formula $\mathrm{Ba}_{(1-\mathrm{x})}\left(\mathrm{HPO}_{4}\right)_{1-2 \mathrm{x}}\left(\mathrm{H}_{2} \mathrm{PO}_{4}\right)_{2 \mathrm{x}}$ (see above), a defective surface was also constructed with a cationic vacancy and completed with two $\mathrm{H}^{+}$. The most favorable structure of this defective surface is shown in Figure 5. The two additional $\mathrm{H}^{+}$are added on two $\mathrm{HPO}_{4}{ }^{2-}$ yielding two $\mathrm{H}_{2} \mathrm{PO}_{4}{ }^{-}$groups. One of the additional $\mathrm{H}$ points down, forming an $\mathrm{H}$ bond with another $\mathrm{HPO}_{4}{ }^{2-}$ deeper in the surface. This orientation is labeled $\mathrm{H}_{\text {down }}$. The other additional $\mathrm{H}$ points up towards the gas phase and is labeled $\mathrm{H}_{\text {up. }}$. No other stable configuration can be found with the two additional $\mathrm{H}^{+}$pointing downward. The adsorption of water is not stronger on this $\mathrm{Ca}^{2+}$ vacancy than on the non- defective surface (adsorption energy of $-84 \mathrm{~kJ} \cdot \mathrm{mol}^{-1} \mathrm{vs.} .-82 \mathrm{~kJ} \cdot \mathrm{mol}^{-1}$ respectively). 


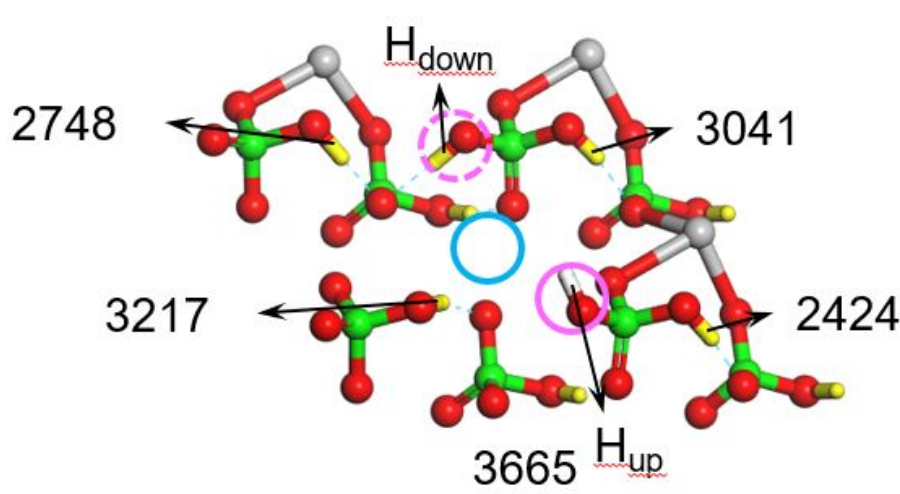

Top view

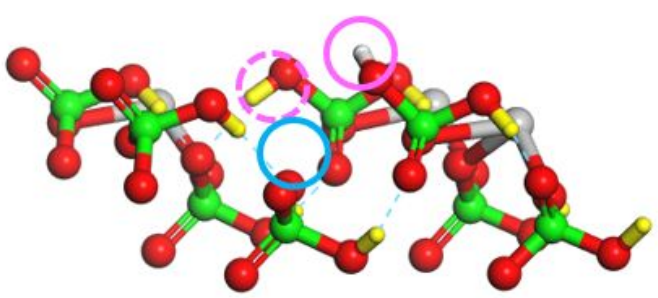

Side view

Figure 5. Computed structure of the defective surface. The $\mathrm{Ca}^{2+}$ vacancy is shown with a blue circle, the $\mathrm{H}_{\text {down }}$ with a pink dashed circle and $\mathrm{H}_{\text {up }}$ with a pink solid circle. The calculated wavenumbers (after rescaling as mentioned in the 2.3 section) of $v(\mathrm{PO}-\mathrm{H})$ vibrations on the first layer are also shown nearby in $\mathrm{cm}^{-1}$. Color-coding: grey for calcium, red for oxygen, green for phosphorus and yellow for hydrogen, except surface $\mathrm{H}_{\mathrm{up}}$ which is marked in white.

To determine if the presence of the $\mathrm{H}_{\text {up }}$ pointing toward the gas phase appears as typical of the presence of a $\mathrm{Ca}^{2+}$ vacancy, we also investigated the likeliness of finding such an orientation in the non-defective fully dehydrated surface. The corresponding results are collected in Table 1 . The most stable structure is Config 1, with four $\mathrm{H}_{\text {down }}$, already discussed and shown in Figure 3. With

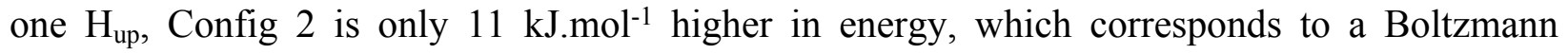
probability of 0.15 at the working temperature of $380{ }^{\circ} \mathrm{C}$. However, with four $\mathrm{H}_{\mathrm{up}}$, Config 3 is much less stable and is clearly very unlikely at this temperature. In other words, the presence of $\mathrm{H}_{\mathrm{up}}$ cannot be attributed only to the presence of $\mathrm{Ca}^{2+}$ vacancy but is also related to thermal effects that favor the re-orientation of the PO-H bond. 
Table 1. Influence of the PO-H orientation in the non-defective dehydrated (010) surface of Brushite on the stability at $380{ }^{\circ} \mathrm{C}$ and the computed wavenumbers of $\mathrm{v}(\mathrm{PO}-\mathrm{H})$, reported after rescaling as mentioned in the 2.3 section.

\begin{tabular}{|c|c|c|c|c|c|}
\hline No. & Surface structure* & $\begin{array}{c}\text { Relative energy } \\
\text { /kJ.mol }{ }^{-1}\end{array}$ & $\begin{array}{l}\text { Boltzmann } \\
\text { distribution }\end{array}$ & $\begin{array}{c}c\left(\mathrm{PO}-\mathrm{H}_{\text {up }}\right) \\
/ \mathrm{cm}^{-1}\end{array}$ & $\begin{array}{c}v\left(\mathrm{PO}-\mathrm{H}_{\text {down }}\right) \\
/ \mathrm{cm}^{-1}\end{array}$ \\
\hline Config 1 & & 0 & 0.84 & 1 & 3170,3161 \\
\hline Config 2 & & 11 & 0.15 & 3691 & $3200-3133$ \\
\hline Config 3 & & 47 & 0.0002 & 3692 & 1 \\
\hline
\end{tabular}

These two orientations (up and down) have a clear spectroscopic signature, with distinct v(POH) stretching vibrations. In the non-defective dehydrated surface, the free PO- $\mathrm{H}_{\text {up }}$ is found to vibrate around $3690 \mathrm{~cm}^{-1}$ while the PO- $\mathrm{H}_{\text {down }}$ vibrations are red-shifted to the $3100-3200 \mathrm{~cm}^{-1}$ range due to their involvement in strong $\mathrm{H}$-bonds with internal $\mathrm{HPO}_{4}{ }^{2-}$ as shown in Table 1 . In a defective surface, the vibration of free PO- $\mathrm{H}_{\mathrm{up}}$ is around $3660 \mathrm{~cm}^{-1}$ and two vibrations of $\mathrm{PO}-\mathrm{H}_{\mathrm{down}}$ are around $3220 \mathrm{~cm}^{-1}$ (Figure 5). These two computed wavenumbers are in agreement with the observations reported in Figure 1 with two bands at 3660 and $3190 \mathrm{~cm}^{-1}$ identified as P-OH vibrations. However, in the defective surface, several $v\left(\mathrm{PO}-\mathrm{H}_{\mathrm{down}}\right)$ wavenumbers are much lower $\left(3041 \mathrm{~cm}^{-1}, 2748 \mathrm{~cm}^{-1}\right.$ and $\left.2424 \mathrm{~cm}^{-1}\right)$ due to the change of the environment induced by the deletion of one $\mathrm{Ca}^{2+}$ atom and the addition of two more protons on the $\mathrm{HPO}_{4}{ }^{2-}$ groups leading to $\mathrm{H}_{2} \mathrm{PO}_{4}{ }^{-}$. They could explain the large width of the band at $3190 \mathrm{~cm}^{-1}$ (see Figure 1) tailing to $2400 \mathrm{~cm}^{-1}$. 
This would imply that the surface of the BaOP catalyst was a defective hydrogen phosphate and hence contained $\mathrm{H}_{2} \mathrm{PO}_{4}^{-}$species.

To further confirm the interpretation of the in situ DRIFT spectra of $\mathrm{BaOP}$ at $380{ }^{\circ} \mathrm{C}$ under He but also under $30 \% \mathrm{H}_{2} \mathrm{O}-\mathrm{He}$ and $30 \% \mathrm{D}_{2} \mathrm{O}-\mathrm{He}$ (Figure 1), we also considered the case with $1 / 8$ ML of water (see Figure 4 and the corresponding discussion). The increase of the band at 3660 $\mathrm{cm}^{-1}$ in presence of water cannot be attributed to water itself since the $\delta$ bending mode of chemisorbed $\mathrm{H}_{2} \mathrm{O}$ at $1600-1630 \mathrm{~cm}^{-1} 39,40$ was not observed. However, all attempts to increase the amount of $\mathrm{P}-\mathrm{OH}$ exposed thanks to water dissociation failed, on both the non-defective dehydrated and the defective surfaces. The only stable structure was obtained in the case of the non-defective surface (as shown in Figure S1) but it is $167 \mathrm{~kJ} \cdot \mathrm{mol}^{-1}$ less stable than when water is not dissociated. Since the increase of the band at $3660 \mathrm{~cm}^{-1}$ cannot be attributed to water itself or to the increase of the number of $\mathrm{POH}$ by water dissociation, we checked if the stability of the $\mathrm{P}-\mathrm{OH}_{\text {up }}$ could be increased by the presence of a chemisorbed water molecule: as shown in Table S2, turning one P$\mathrm{OH}_{\text {down }}$ into a $\mathrm{P}-\mathrm{OH}_{\text {up }}$ costs $9 \mathrm{~kJ} \cdot \mathrm{mol}^{-1}$, which is very close to the $11 \mathrm{~kJ} \cdot \mathrm{mol}^{-1}$ that was needed in absence of water (Table 1): the effect is not significant. Finally, we inferred that it could be related to hydrolysis of the small amount of $\alpha-\mathrm{Ba}_{2} \mathrm{P}_{2} \mathrm{O}_{7}$ present in the $\mathrm{BaOP}$ catalyst leading to $\mathrm{BaHPO}_{4}$ formation and to an increase in the concentration of cationic vacancy in the hydrogen phosphate layer lying over $\mathrm{Ba}_{3}\left(\mathrm{PO}_{4}\right)_{2}$ crystallites, which would be favored by water. For $\mathrm{BaHPO}_{4}$, the hydrolysis reaction is proposed to occur according to:

$$
\mathrm{BaHPO}_{4}+\mathrm{H}_{2} \mathrm{O}=>\mathrm{Ba}_{(1-\mathrm{x})}\left(\mathrm{HPO}_{4}\right)_{1-2 \mathrm{x}}\left(\mathrm{H}_{2} \mathrm{PO}_{4}\right)_{2 \mathrm{x}}+\mathrm{xBa}^{2+}+2 \mathrm{xOH}^{-}
$$

Note that similar dissolution processes were reported in the liquid phase $\mathrm{e}^{42,43}$ and could be more favorable for sub-stoichiometric brushite containing cationic vacancies. 


\subsection{Acidity measurements by IR spectroscopy}

The FTIR spectrum of pyridine adsorbed on BaOP plotted in Figure S2 (supplementary material) contained bands at $1614,1592,1574,1489$ and $1441 \mathrm{~cm}^{-1}$ which were attributed to pyridine coordinated to Lewis acid sites (LAS) or in H-bonding. ${ }^{44,45}$ Observation of two $8 \mathrm{a}$ vibrational modes at 1614 and $1592 \mathrm{~cm}^{-1}$ revealed the presence of two different coordination sites. Considering their shifts compared to pyridine in liquid phase $\left(1583 \mathrm{~cm}^{-1}\right)$, they were attributed to moderate Lewis acid and H-bonding sites, respectively. The three other bands corresponded to $8 \mathrm{~b}$, 19a and 19b modes, respectively. ${ }^{44,45}$ The absence of band around $1540-1550 \mathrm{~cm}^{-1}$ typical of pyridinium cations indicated the absence of Brønsted acid sites able to protonate pyridine.

As pyridine $(\mathrm{pKa}=5.2)$ could be too weak to react with BAS, adsorption-desorption of lutidine $(\mathrm{pKa}=6.6)$ was followed by FTIR. Spectra recorded at different desorption temperatures are plotted in Figure 6.

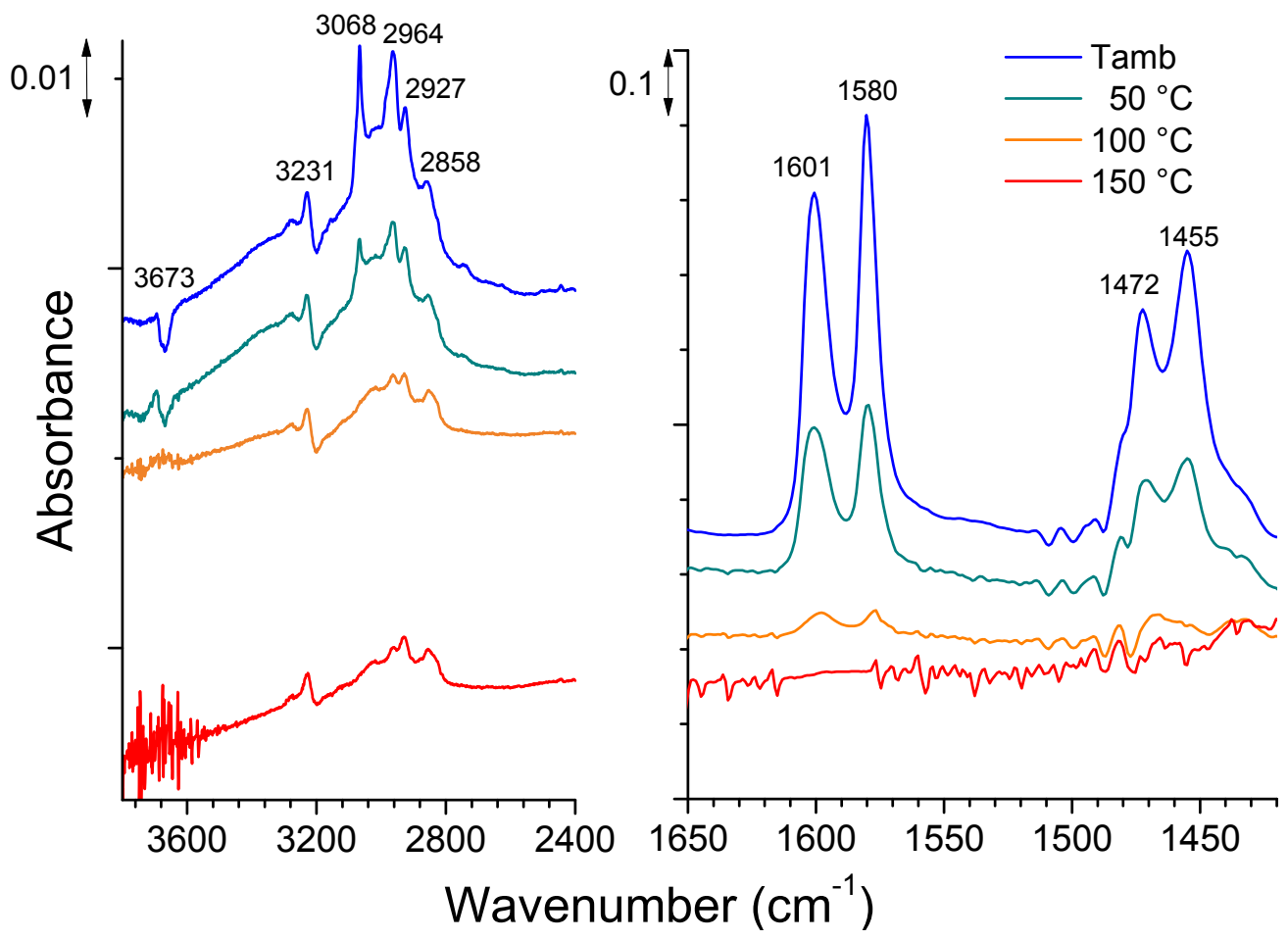

Figure 6. Evolution of the FTIR spectra of BaOP after adsorption of lutidine at $\mathrm{T}_{\mathrm{amb}}$ and desorption under vacuum at increasing temperature. 
At room temperature, bands were observed at 1601, 1580, 1472 and $1455 \mathrm{~cm}^{-1}$ which were attributed to the $8 \mathrm{a}, 8 \mathrm{~b}, 19 \mathrm{a}$ and $19 \mathrm{~b}$ vibrational modes of lutidine coordinated to LAS or in Hbonding ${ }^{46,47}$ while the negative $v(\mathrm{PO}-\mathrm{H})$ band at $3673 \mathrm{~cm}^{-1}$ revealed structural modifications of $\mathrm{POH}_{\text {up }}$ species that could arise from interaction between $\mathrm{POH}_{\text {up }}$ species and lutidine. It was not possible to know if the broad band around $3200 \mathrm{~cm}^{-1}$ and attributed to $\mathrm{POH}_{\mathrm{down}}$ was affected because of superimposition of $v\left(\mathrm{CH}_{3}\right)$ and $v(\mathrm{CH})$ stretching vibrations of lutidine. The 8 a mode of lutidine is very sensitive to the adsorption mode and its small shift compared to the liquid phase $\left(+7 \mathrm{~cm}^{-1}\right)$ was typical of $\mathrm{H}$-bonded species. The 8 a mode of lutidinium cations located at $1640-$ $1655 \mathrm{~cm}^{-1}$ was not observed showing that $\mathrm{POH}$ species were not able to protonate lutidine. Increasing the desorption temperature, the bands of H-bonded lutidine disappeared in parallel to the negative $v(\mathrm{PO}-\mathrm{H})$ band confirming their interdependence. The steric hindrance of methyl groups of lutidine could explain such molecule did not probe moderated LAS contrarily to pyridine. ${ }^{47}$

The in situ FTIR spectra recorded at adsorption equilibrium of $\mathrm{NH}_{3}$ are shown on Figure 7 from 120 to $7^{\circ} \mathrm{C}$. They all contain one band at $1630 \mathrm{~cm}^{-1}$, numerous bands between 3200 and 3400 $\mathrm{cm}^{-1}$ and a negative band at $3670 \mathrm{~cm}^{-1}$. They disappeared above $200{ }^{\circ} \mathrm{C}$ in good agreement with TPD measurements. Comparison between the evolutions of the experimental coverage and the one calculated using the Temkin model (Figure S3) led to adsorption heat values of $\mathrm{E}_{0}=65 \mathrm{~kJ}^{\mathrm{mol}}{ }^{-1}$ and $\mathrm{E}_{1}=48 \mathrm{~kJ} \cdot \mathrm{mol}^{-1}$. Such low values were typical of weak adsorption sites. ${ }^{17}$ 


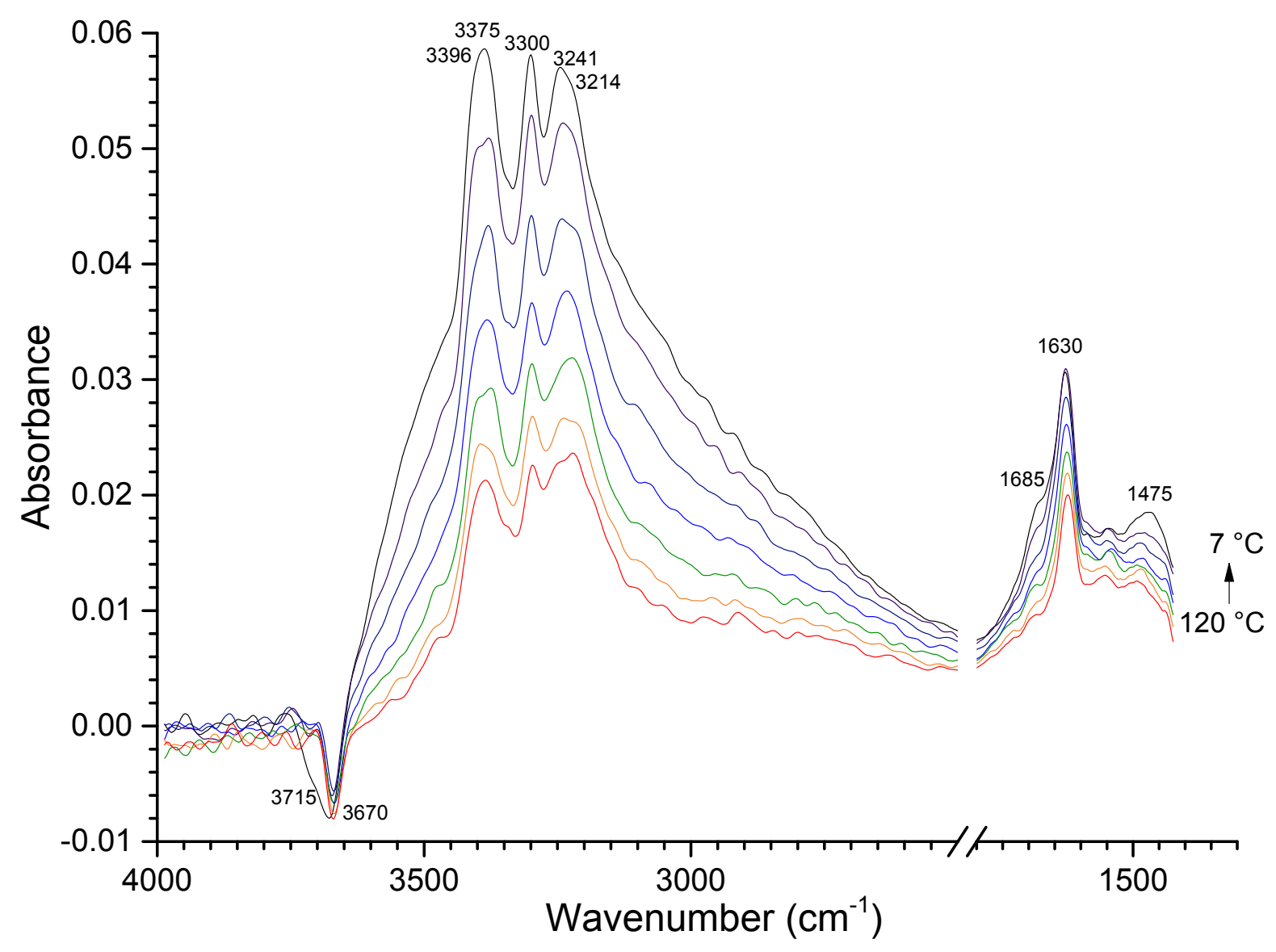

Figure 7. Evolution of the IR bands of $\mathrm{NH}_{3}$ adsorbed species on pre-treated $\mathrm{BaOP}$ catalyst recorded under $2 \% \mathrm{NH}_{3}$ He flow from 120 to $7{ }^{\circ} \mathrm{C}$. The backgrounds correspond to the spectra recorded after pretreatment under He flow at the same temperatures, mass of the pellet $53 \mathrm{mg}$.

We also established the relative stability of various ammonia surface concentrations as function of the temperature using ab initio thermochemistry (see Figure S4). When $\mathrm{T}<145{ }^{\circ} \mathrm{C}$, the coverage of $\mathrm{NH}_{3}$ was $\theta\left(\mathrm{NH}_{3}\right)=1 \mathrm{ML}$ (one ammonia per surface phosphate). It decreased to $1 / 2$ ML from $145^{\circ} \mathrm{C}$ to $162^{\circ} \mathrm{C}$. Above $162^{\circ} \mathrm{C}$, the surface was predicted to be bare, with no ammonia, in agreement with our experimental observations. To sustain the attribution of the bands and identify the corresponding sites, we show the most important predicted wavenumbers obtained on the dehydrated surfaces with a coverage of $\theta\left(\mathrm{NH}_{3}\right)=1 / 4 \mathrm{ML}$ in Figure 8 . The ones obtained with a 
higher coverage, such as 1/2 ML, were found similar (see Table S3).

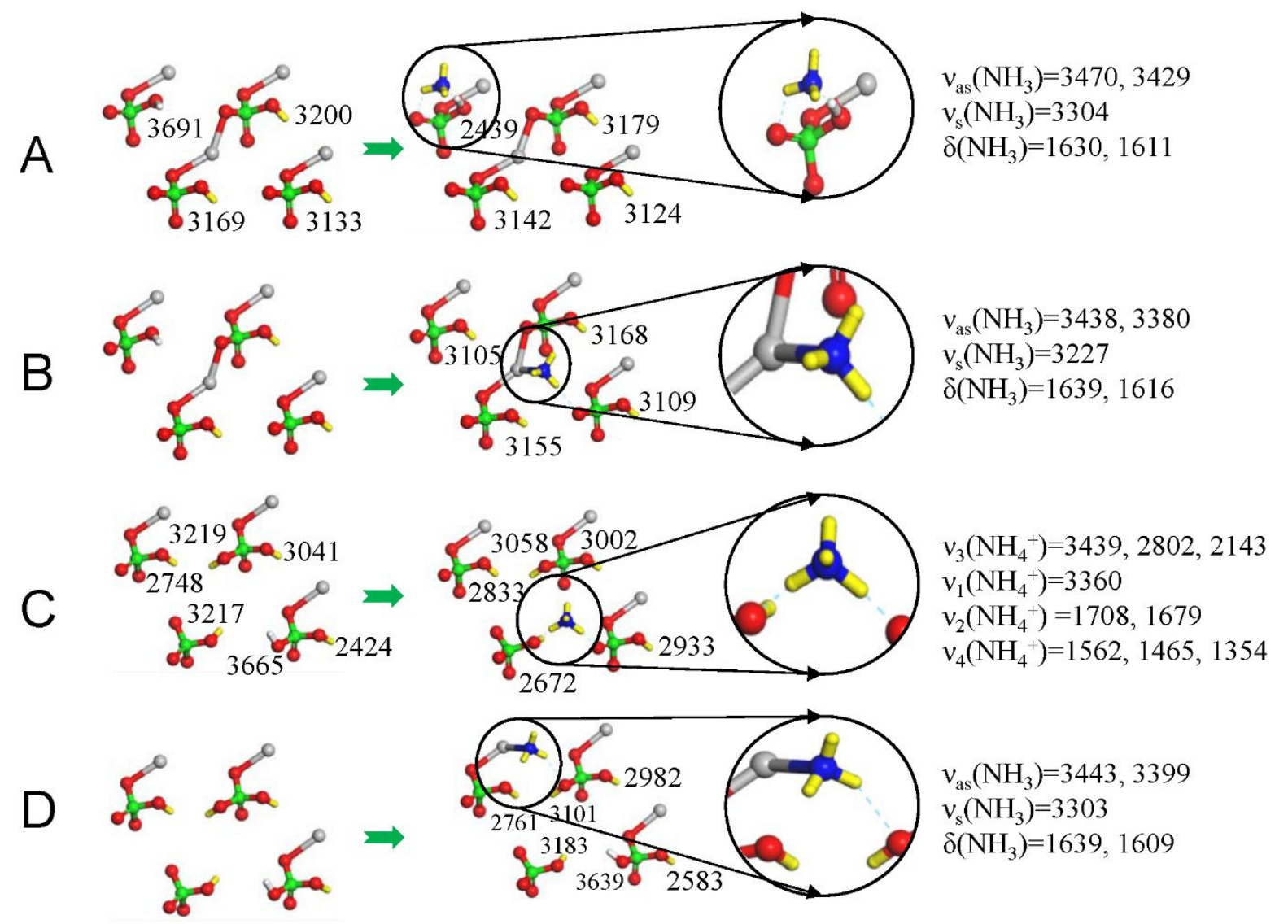

Figure 8. Structures (top view) and computed wavenumbers (in $\left.\mathrm{cm}^{-1}\right)$ of the $v(\mathrm{PO}-\mathrm{H})$ stretching vibrations and of the $\mathrm{NH}_{3}$ or $\mathrm{NH}_{4}{ }^{+}$vibrations after the adsorption of $\mathrm{NH}_{3}$ on the non-defective dehydrated surface (A and B) and on the defective surface $(\mathrm{C}$ and $\mathrm{D})$ at a coverage of $\theta\left(\mathrm{NH}_{3}\right)=1 / 4 \mathrm{ML}$. The corresponding adsorption energies are reported in Table 2. Color-coding: grey for calcium, red for oxygen, green for phosphorus, blue for nitrogen and yellow for hydrogen, except surface $\mathrm{H}_{\mathrm{up}}$, which is marked in white.

The negative band at $3670 \mathrm{~cm}^{-1}$ indicated that $\mathrm{POH}_{\text {up }}$ species are modified by adsorbed $\mathrm{NH}_{3}$. Thus, the adsorption of $\mathrm{NH}_{3}$ was considered on the Config 2 of the non-defective surface (see Table 1), which presented some $\mathrm{POH}_{\text {up }}$ species, and on the defective surface. In both cases, the interaction with the BAS (the $\left.\mathrm{POH}_{\text {up }}\right)$ and the LAS $\left(\mathrm{Ca}^{2+}\right.$ in our model that stands for $\mathrm{Ba}^{2+}$ in the BaOP catalyst) were considered. The corresponding adsorption energies are provided in Table 2 . 
Table 2. Adsorption energy of water and ammonia on the non-defective and defective surface corresponding to the structures shown in Figure 8 and Figure 10. The adsorption of ammonia is given as a successive adsorption after the adsorption of water on structures E, F and G.

\begin{tabular}{lllcc}
\hline Label & Surface & Structure description & $\mathrm{E}_{\text {ads }}\left(\mathrm{H}_{2} \mathrm{O}\right)$ & $\mathrm{E}_{\text {ads }}\left(\mathrm{NH}_{3}\right)$ \\
& & $\mathrm{kJ} \cdot \mathrm{mol}^{-1}$ & $\mathrm{~kJ} \cdot \mathrm{mol}^{-1}$ \\
\hline A & Non-defective & $\mathrm{NH}_{3}$ is h-bounded to a $\mathrm{P}-\mathrm{OH}_{\text {up }}$ & - & -48 \\
B & Non-defective & $\mathrm{NH}_{3}$ is in interaction with $\mathrm{Ca}^{2+}$ & - & -89 \\
C & Defective & $\mathrm{NH}_{4}^{+}$ & - & -118 \\
D & Defective & $\mathrm{NH}_{3}$ is in interaction with $\mathrm{Ca}^{2+}$ & - & -84 \\
E & Non defective & $\mathrm{NH}_{3}$ is in interaction with $\mathrm{Ca}^{2+}$ & -90 & -95 \\
F & Non-defective & $\mathrm{NH}_{4}{ }^{+}$ & -90 & -46 \\
G & Defective & $\mathrm{NH}_{4}^{+}$ & -82 & -108 \\
\hline
\end{tabular}

With a low adsorption energy $\left(-48 \mathrm{~kJ} \cdot \mathrm{mol}^{-1}\right)$, the adsorption on the BAS (structure A) is less likely than on the LAS of the dehydrated non-defective surface (structure B, -89 $\left.\mathrm{kJ}^{\mathrm{mol}}{ }^{-1}\right)$. The contrast between these two site types is likely to be reduced since here we modeled $\mathrm{Ba}^{2+}$ by a stronger LAS, namely $\mathrm{Ca}^{2+}$. On the defective surface, it was the opposite situation with an adsorption on the LAS (structure D, $-84 \mathrm{~kJ}_{\mathrm{mol}}^{-1}$ ) less stabilizing than on the BAS (structure $\mathrm{C},-118 \mathrm{~kJ}_{\mathrm{mol}}{ }^{-1}$ ), a difference that is expected to be even stronger for the weak LAS $\mathrm{Ba}^{2+}$. In this defective case, the adsorbed $\mathrm{NH}_{3}$ even captured 
a proton of $\mathrm{H}_{2} \mathrm{PO}_{4}^{-}$yielding $\mathrm{NH}_{4}{ }^{+}, \mathrm{H}$ bonded with several nearby oxygen atoms. Conversely, the generation of $\mathrm{NH}_{4}{ }^{+}$from the proton transfer from $\mathrm{HPO}_{4}{ }^{2-}$ to $\mathrm{NH}_{3}$ was found to be very unlikely on the non-defective dehydrated surface with an adsorption energy much weaker than the non-dissociative adsorption $\left(-12 \mathrm{~kJ} \cdot \mathrm{mol}^{-1} \mathrm{vs} .-89 \mathrm{~kJ} \cdot \mathrm{mol}^{-1}\right.$, Figure S5).

The experimental spectra contained one band at $1630 \mathrm{~cm}^{-1}$ typical of Lewis coordination and/or H-bonding $\left(\delta\left(\mathrm{NH}_{3}\right)\right.$ vibration $) .{ }^{48}$ This vibration mode is doubly degenerated in free $\mathrm{NH}_{3}$ but nonsymmetric environment slightly split the band in the computed spectra. It was predicted to be not sensitive to the type of interaction since it was computed at $1630,1611 \mathrm{~cm}^{-1}$ when $\mathrm{NH}_{3}$ was $\mathrm{H}$ bonded to $\mathrm{P}_{-} \mathrm{OH}_{\text {up }}$ (Figure 8A) and at $1639,1609 \mathrm{~cm}^{-1}$ when $\mathrm{NH}_{3}$ was in interaction with a LAS (Figure 8B and D). The $v\left(\mathrm{NH}_{3}\right)$ stretching vibrations were more sensitive to the adsorption site. The symmetric mode was strongly red-shifted $\left(3227 \mathrm{~cm}^{-1}\right)$ when $\mathrm{NH}_{3}$ was in interaction with the LAS on the non-defective surface (Figure 8B) compared with cases where it was in interaction with the same site on the defective surface $\left(3303 \mathrm{~cm}^{-1}\right.$, Figure $\left.8 \mathrm{D}\right)$ or $\mathrm{H}$-bonded to $\mathrm{PO}-\mathrm{H}_{\text {up }}$ of the non-defective surface $\left(3304 \mathrm{~cm}^{-1}\right.$, Figure $\left.8 \mathrm{~A}\right)$. The asymmetric vibrations were all found in a range of $3380-3470 \mathrm{~cm}^{-1}$. All these bands were compatible with the experimental observation of a rather complicated $3200-3400 \mathrm{~cm}^{-1}$ spectral range with bands at 3396, 3375, 3300, 3241 and $3214 \mathrm{~cm}^{-1}$ superimposed to an asymmetric broad one (Figure 7). The first two were attributed to $v_{\text {asym }}\left(\mathrm{NH}_{3}\right)$ vibrations and the third one to $v_{\text {sym }}\left(\mathrm{NH}_{3}\right)$. Note that $v_{\text {asym }}\left(\mathrm{NH}_{3}\right)$ vibrations are doubly degenerated for free $\mathrm{NH}_{3}$ (E mode). Observation of two $v_{\text {asym }}\left(\mathrm{NH}_{3}\right)$ bands and one $v_{\text {sym }}\left(\mathrm{NH}_{3}\right)$ band implies a symmetry lowering compared to $\mathrm{C}_{3 \mathrm{v}}$. Attribution of the two last bands at 3241 and $3214 \mathrm{~cm}^{-1}$ was 
not obvious since it could either correspond to overtones of $\delta_{\text {asym }}\left(\mathrm{NH}_{3}\right)$ and to $v_{1}\left(\mathrm{NH}_{4}{ }^{+}\right)$ vibrations ${ }^{49,50}$ but also to $v_{\text {sym }}\left(\mathrm{NH}_{3}\right)$ with $\mathrm{NH}_{3}$ in interaction with the Lewis site on the nondefective surface $\left(3227 \mathrm{~cm}^{-1}\right.$, Figure $\left.8 \mathrm{~B}\right)$ or to $v(\mathrm{PO}-\mathrm{H})$ vibrations of $\mathrm{POH}_{\text {down }}$ species. As these bands were kept upon heating to $120^{\circ} \mathrm{C}$ while $v_{4}\left(\mathrm{NH}_{4}{ }^{+}\right)$at $1475 \mathrm{~cm}^{-1} 49,50$ disappeared above $7{ }^{\circ} \mathrm{C}$, attribution to $v_{1}\left(\mathrm{NH}_{4}^{+}\right)$was ruled out.

Observation of broad band tailing to $2400 \mathrm{~cm}^{-1}$ strongly suggested higher contribution of v(POH) vibrations due to $\mathrm{POH}_{\text {down }}$. Indeed, some $\mathrm{POH}_{\text {down }}$ vibrations were predicted to be red-shifted by the $\mathrm{NH}_{3}$ absorption with bands shifting from 3169 to $3139 \mathrm{~cm}^{-1}$ for instance (see Figure $8 \mathrm{~A}$ ). In addition, the presence of $\mathrm{Ca}^{2+}$ vacancies in the defective structure would also yield to the observation of vibrations as low as $2583 \mathrm{~cm}^{-1}$ related to the presence of $\mathrm{H}_{2} \mathrm{PO}_{4}^{-}$species (Figure 8D). Last, when $\mathrm{NH}_{3}$ was $\mathrm{H}$ bonded directly to $\mathrm{PO}-\mathrm{H}_{\text {up }}$ (Figure 8A), the $v\left(\mathrm{PO}-\mathrm{H}_{\text {up }}\right)$ band at 3691 $\mathrm{cm}^{-1}$ shifted down to $2439 \mathrm{~cm}^{-1}$ due to the strong H-bond. This corresponds to a zone where a small absorbance was seen in the experimental spectra. The orientation of the PO- $\mathrm{H}_{\text {up }}$ was also affected in the case of an interaction of $\mathrm{NH}_{3}$ with the LAS, despite the lack of direct interaction. It rotated from up to down, inducing a strong red shift of $v\left(\mathrm{PO}-\mathrm{H}_{\mathrm{up}}\right)$ from 3691 to $3105 \mathrm{~cm}^{-1}$ and the red shift of the three $v\left(\mathrm{PO}-\mathrm{H}_{\text {down }}\right)$ to $3100-3200 \mathrm{~cm}^{-1}$ as shown in Figure $8 \mathrm{~B}$ and D. This is in line with the experimental observations regarding the disappearing of the band at $3670 \mathrm{~cm}^{-1}$ and the broad band in the range of $2800-3200 \mathrm{~cm}^{-1}$. Finally, the band at $3241 \mathrm{~cm}^{-1}$ could correspond to the $v_{\mathrm{sym}}\left(\mathrm{NH}_{3}\right)$ vibration of $\mathrm{NH}_{3}$ adsorbed on the LAS of the non-defective surface while the shoulder at 3214 $\mathrm{cm}^{-1}$ would be assigned to changes in the $\mathrm{POH}_{\text {down }}$ signature. Attribution of the bands 3241 and $3214 \mathrm{~cm}^{-1}$ to two different species (adsorbed $\mathrm{NH}_{3}$ and $\mathrm{POH}_{\text {down }}$, respectively) was confirmed by the change of their relative intensity with the temperature (Figure 7).

The negative shoulder observed at $3715 \mathrm{~cm}^{-1}$ only on the spectrum recorded to $7{ }^{\circ} \mathrm{C}$ (below 
RT) was assigned to $v\left(\mathrm{H}_{2} \mathrm{O}\right)$ due to traces of physisorbed water leading to the spontaneous reaction: 16,39

$$
\mathrm{NH}_{3}+\mathrm{H}_{2} \mathrm{O}_{\mathrm{ads}} \Leftrightarrow\left(\mathrm{NH}_{4}^{+}\right)_{\mathrm{ads}}+\mathrm{OH}^{-}{ }_{\mathrm{ads}}
$$

Such reaction which did occur only at $7{ }^{\circ} \mathrm{C}$ also explained observation of the bending $v_{4}\left(\mathrm{NH}_{4}^{+}\right)$ and $v_{2}\left(\mathrm{NH}_{4}{ }^{+}\right)$vibrations bands at 1475 and $1685 \mathrm{~cm}^{-1}$, respectively. ${ }^{49,50}$ The latter one is observed by IR only when symmetry of $\mathrm{NH}_{4}{ }^{+}$cations is lower than $\mathrm{T}_{\mathrm{d}} \cdot{ }^{49,50} \mathrm{DFT}$ computations provided another possible explanation on $\mathrm{NH}_{4}{ }^{+}$formation. Indeed, traces of physisorbed water at low temperature could increase the amount of $\mathrm{Ca}^{2+}$ vacancies (see section 3.2), which promotes the formation of $\mathrm{NH}_{4}^{+}$. Their presence was predicted on the defective surface, with strong adsorption energy of $-118 \mathrm{~kJ} \mathrm{~mol}^{-1}$ (Table 2). The computed $\mathrm{NH}_{4}{ }^{+}$vibration bands were split by the environment. By comparison with the observed ones (1475 and $\left.1685 \mathrm{~cm}^{-1}\right)$, two bands were found to be the major ones (1465 and $1679 \mathrm{~cm}^{-1}$, see Figure 8C).

To sum up, the interaction of $\mathrm{NH}_{3}$ with the $\mathrm{POH}$ groups by $\mathrm{H}$-bonding without significant protonation of the non-defective surface could not be discarded based on the infrared signature. However, it was found to be less likely based on energetic consideration since it had the weakest adsorption energy (Table 2). Even upon interaction with the LAS, the $v\left(\mathrm{PO}-\mathrm{H}_{\mathrm{up}}\right)$ band was found to disappear due to the re-orientation of the PO-H bond downward. Bands at 3396-3375, 3300, 3241 and $3214 \mathrm{~cm}^{-1}$ were attributed to degenerated $v_{\text {asym }}\left(\mathrm{NH}_{3}\right), v_{\text {sym }}\left(\mathrm{NH}_{3}\right)$ of $\mathrm{NH}_{3}$ in interaction with the LAS of the defective surface, $v_{\text {sym }}\left(\mathrm{NH}_{3}\right)$ of $\mathrm{NH}_{3}$ in interaction with the LAS of the nondefective surface and to $v\left(\mathrm{PO}-\mathrm{H}_{\text {down }}\right)$ respectively. The broad band tailing at $2400 \mathrm{~cm}^{-1}$ was due to the reorganization of the $\mathrm{PO}-\mathrm{H}_{\text {down }}$ upon adsorption.

\subsection{Water effect on acidity}


In situ acidity measurements were achieved at adsorption equilibrium under $1 \% \mathrm{NH}_{3}-3 \% \mathrm{H}_{2} \mathrm{O}-$

He flow and FTIR spectra are plotted in Figure 9. The absorbance value of the $v_{4}\left(\mathrm{NH}_{4}{ }^{+}\right)$band at $1458 \mathrm{~cm}^{-1}$ was strongly increased evidencing a higher Brønsted acidity formed under water vapor. ${ }^{20,39}$ As the band at $1640 \mathrm{~cm}^{-1}$ could be attributed to either $\delta\left(\mathrm{NH}_{3}\right)$ and $\delta\left(\mathrm{H}_{2} \mathrm{O}\right)$ vibrations and as no $v_{\text {asym }}\left(\mathrm{NH}_{3}\right)$ vibrations around $3300-3400 \mathrm{~cm}^{-1}$ were distinguishable from the broad band at $3420 \mathrm{~cm}^{-1}$ due to $v\left(\mathrm{H}_{2} \mathrm{O}\right)$ of chemisorbed water, the presence of chemisorbed $\mathrm{NH}_{3}$ species remained questionable. Note that the shoulder observable at $3220 \mathrm{~cm}^{-1}$ above $40{ }^{\circ} \mathrm{C}$ could be attributed to $v_{1}\left(\mathrm{NH}_{4}{ }^{+}\right)$vibrations associated with $v_{4}\left(\mathrm{NH}_{4}{ }^{+}\right)$at $1458 \mathrm{~cm}^{-1} \cdot{ }^{49,50}$ Finally, the small band at $3692 \mathrm{~cm}^{-1}$ can correspond to $v\left(\mathrm{PO}-\mathrm{H}_{\mathrm{up}}\right)$ and to $\mathrm{v}\left(\mathrm{H}_{2} \mathrm{O}_{\mathrm{ads}}\right)$ as already discussed earlier.

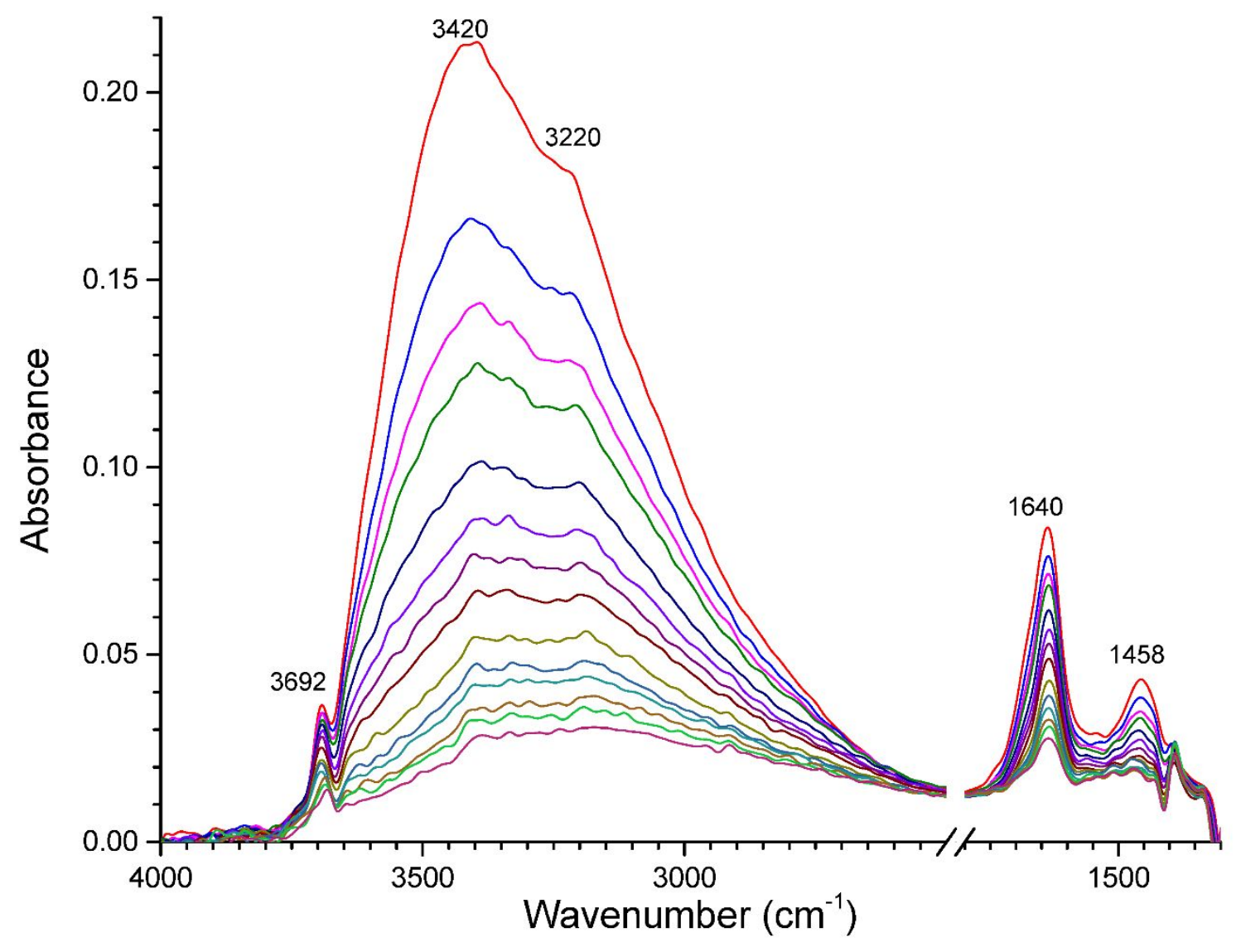


Figure 9. Evolution of the IR bands of $\mathrm{NH}_{3}$ adsorbed species on pre-treated $\mathrm{BaOP}$ catalyst recorded under $1 \% \mathrm{NH}_{3}$ $3 \% \mathrm{H}_{2} \mathrm{O}-\mathrm{He}$ flow from 172 to $28^{\circ} \mathrm{C}$. The backgrounds correspond to the spectra recorded after pretreatment under He flow at the same temperatures, mass of the pellet $53 \mathrm{mg}$.

DFT computations provided an atomistic view of the adsorption of ammonia on the BAS and the LAS of both the non-defective and defective surface, but including water co-adsorption $\left(\theta\left(\mathrm{H}_{2} \mathrm{O}\right)=1 / 8 \mathrm{ML}\right)$ assuming that the presence of ammonia does not modify strongly the predicted water coverage. The corresponding structures along with their wavenumbers are shown in Figure 10 and the adsorption energies are reported in Table 2. The computed vibrations of the three structures are compatible with the experimental observations.

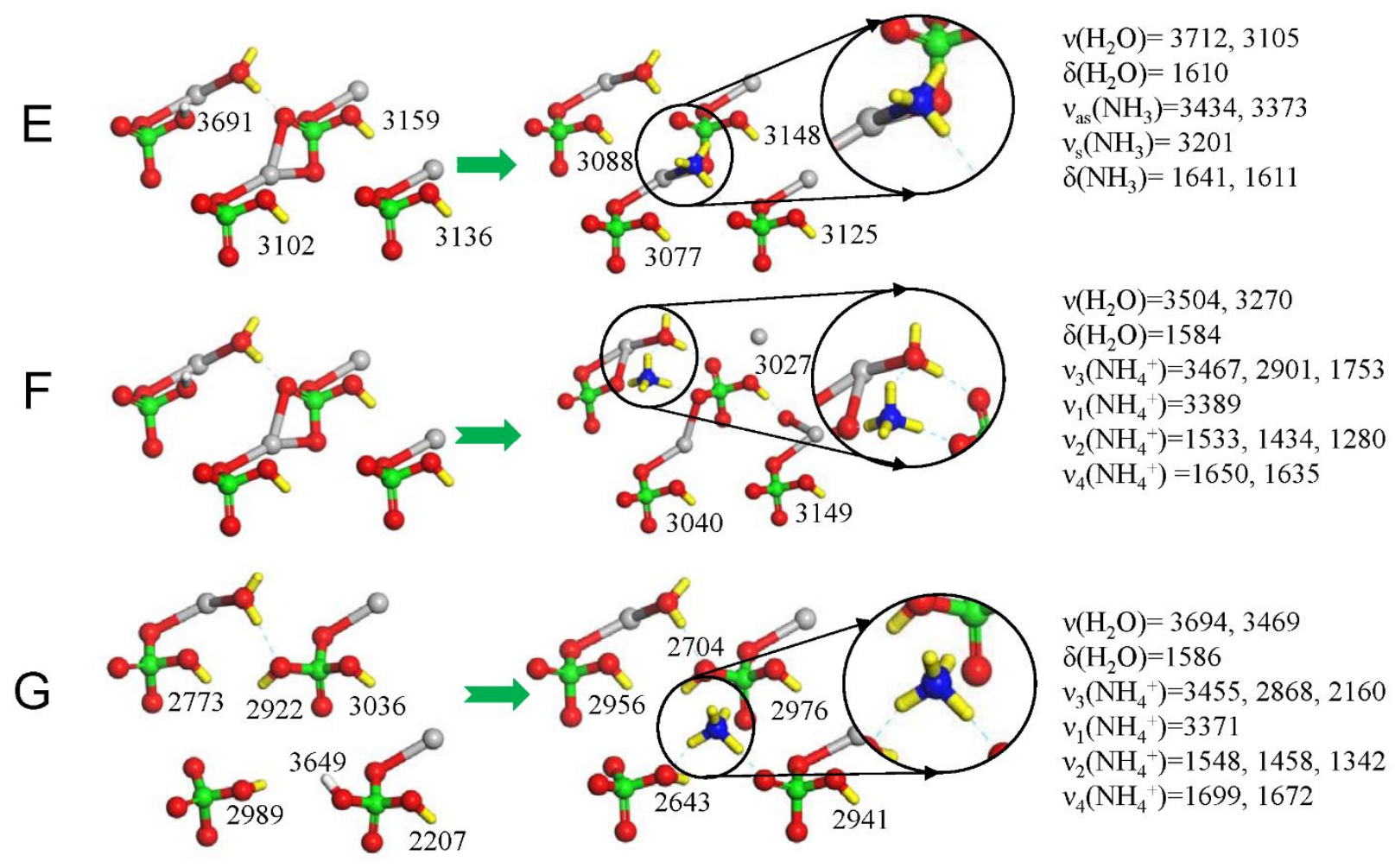

Figure 10. Structures and computed wavenumbers $\left(\right.$ in $\left.\mathrm{cm}^{-1}\right)$ of the $v(\mathrm{PO}-\mathrm{H})$ stretching vibrations, water vibration and of the $\mathrm{NH}_{3}$ or $\mathrm{NH}_{4}{ }^{+}$vibration after the adsorption of $\mathrm{NH}_{3}$ on the non-defective dehydrated surface (E and $\left.\mathrm{F}\right)$ and on the defective surface $(\mathrm{G})$. The corresponding adsorption energies are reported in Table 2. Color-coding: grey for 
calcium, red for oxygen, green for phosphorus, blue for nitrogen and yellow for hydrogen, except surface $\mathrm{H}_{\text {up }}$ which is marked in white.

On the non-defective surface, the presence of a water molecule does not modify the interaction of $\mathrm{NH}_{3}$ with the LAS site (structure E), which was still found being the most stable adsorption site with adsorption energy of $-95 \mathrm{~kJ} \mathrm{~mol}^{-1}$ (Table 2). Noticeably, the $\mathrm{P}-\mathrm{OH}_{\text {up }}$ shifts to a $\mathrm{P}-\mathrm{OH}_{\text {down }}$ during this adsorption despite the absence of a direct interaction with $\mathrm{NH}_{3}$, yielding to a predicted disappearance of the vibration at $3691 \mathrm{~cm}^{-1}$ but with the appearance of a band at $3712 \mathrm{~cm}^{-1}$ related to the elongation of $\mathrm{OH}$ in the chemisorbed water. In other words, while the presence of $\mathrm{NH}_{3}$ was questionable based on the experimental spectrum, it seems rather likely at distance of defective sites since structure $\mathrm{E}$ is more stable than the ones yielding to ammonium following a proton transfer from water or the BAS of the surface. Still, co-adsorbed water made the BAS more acidic. Indeed, interaction of $\mathrm{NH}_{3}$ with the $\mathrm{PO}-\mathrm{H}_{\text {up }}$ generated $\mathrm{NH}_{4}{ }^{+}$(structure $\mathrm{F}$ ) with adsorption energy of $-46 \mathrm{~kJ} . \mathrm{mol}^{-1}$ (Table 2), a process strongly facilitated by the presence of water even if it does not participate directly, thanks to an extra stabilizing $\mathrm{H}$ bond. On the totally dehydrated surface, the same reactive adsorption yielded only to adsorption energy of $-22 \mathrm{~kJ} \cdot \mathrm{mol}^{-1}$. This could explain the increase of the $\mathrm{NH}_{4}{ }^{+}$band absorption in presence of ammonia co-fed with water in comparison with ammonia only. Another source of $\mathrm{NH}_{4}{ }^{+}$could be the increase of $\mathrm{Ca}^{2+}$ vacancies promoted by the presence of water (see section 3.2) since $\mathrm{NH}_{3}$ easily turns into $\mathrm{NH}_{4}{ }^{+}$by capturing the proton of the $\mathrm{H}_{2} \mathrm{PO}_{4}^{-}$group close to the $\mathrm{Ca}^{2+}$ vacancy (structure $\mathrm{G}$ ), with strong adsorption energy of -108 kJ.mol ${ }^{-1}$ (Table 2).

\section{CONCLUSIONS}


In this work, acidic properties of BaOP catalyst were investigated combining FTIR spectra achieved at the dehydrated state and under water vapour and DFT calculations. Such catalyst efficient for the dehydration of lactic acid to acrylic acid was previously shown to contain a surface mono/dihydrogen phosphate amorphous layer composed by $\mathrm{Ba}^{2+}$ cations, $\mathrm{P}=\mathrm{O}$ and $\mathrm{POH}$ groups. Therefore, the surface layer was simulated by non-defective and defective MPOH structure. Adsorption of pyridine, lutidine and $\mathrm{NH}_{3}$ at the surface of $\mathrm{BaOP}$ catalyst revealed the presence of moderate LAS and of $\mathrm{POH}$ groups without significant protonation for the first two probe molecules. Ammonia was found to mainly interact with the LAS on both the non-defective surface and the defective surface while the $\mathrm{PO}-\mathrm{H}_{\text {up }}$ surface groups are reoriented downward. Formation of BAS was shown to occur under water vapor by co-adsorption of $\mathrm{NH}_{3}$ and $\mathrm{H}_{2} \mathrm{O}$. The phenomenon cannot be explained by dissociation of $\mathrm{H}_{2} \mathrm{O}$ molecules as shown by DFT calculations. In fact, the presence of water does not modify the interaction of $\mathrm{NH}_{3}$ with the LAS sites of non-defective surface but made the BAS more acidic. The presence of water could also promote formation of defective surface and hence $\mathrm{H}_{2} \mathrm{PO}_{4}{ }^{-}$groups which easily react with $\mathrm{NH}_{3}$ to form $\mathrm{NH}_{4}{ }^{+}$.

\section{ASSOCIATED CONTENT}

The Supporting Information is available free of charge on the ACS Publications website at DOI: $\mathrm{XXX}$

Scaling factor of $\mathrm{NH}_{3}$ vibrational modes, Influence of the $\mathrm{PO}-\mathrm{H}$ orientation in the non-defective partially hydrated $(010)$ surface $\left(\theta\left(\mathrm{H}_{2} \mathrm{O}\right)=1 / 8 \mathrm{ML}\right)$ on the stability at $380^{\circ} \mathrm{C}$ and the computed wavenumbers of $v(\mathrm{PO}-\mathrm{H})$, wavenumbers of $\mathrm{NH}_{3}$ and $\mathrm{NH}_{4}{ }^{+}$co-adsorption on defective surface, dissociated $\mathrm{H}_{2} \mathrm{O}$ on defective surface, Structure of the dissociated $\mathrm{H}_{2} \mathrm{O}$ on the non-defective surface, FTIR spectrum of adsorbed pyridine, Experimental evolutions of the coverage of the $\mathrm{NH}_{3}$ adsorbed species with the adsorption temperature and theoretical curve obtained using Temkin 
model; surface energy in $\mathrm{eV} / \AA^{2}$ of Brushite (010) surfaces with various coverages; possible configuration of the ammonium cation on a dehydrated surface; archive of raw data from computations including structures and frequencies.

\section{AUTHOR INFORMATION \\ Corresponding Authors \\ *E-mail: stephane.loridant@ircelyon.univ-lyon1.fr \\ *E-mail: carine.michel@ens-lyon.fr \\ ORCID}

Stéphane Loridant: 0000-0001-8590-433X

Carine Michel: 0000-0002-4501-7194

Notes

The authors declare no competing financial interest.

\section{ACKNOWLEDGEMENTS}

This work was supported by French ANR Program Chimie Durable-Industries-Innovation (CD2I) GALAC, a joint project between IRCELYON, UCCS, LC/ENS-Lyon and Novance company. Laurent Piccolo is acknowledged for access to the IR apparatus founded by the project DINAMIC (reference ANR-2011-BS10-009). 


\section{REFERENCES}

(1) Mäki-Arvela, P.; Simakova, I.L.; Salmi, T.; Murzin, D.Y. Production of lactic acid/lactates from biomass and their catalytic transformations to commodities. Chem. Rev. 2013, 114, 19091971.

(2) Blanco, E.; Loridant, S.; Pinel, C. Valorization of lactic acid and derivatives to acrylic acid derivatives: review of mechanistic studies. In Reaction Pathways and Mechanisms in Thermocatalytic Biomass Conversion II, Schlaf, M.; Zhang, Z. C., Eds.; Springer, 2016, Chapter 3, pp39-62.

(3) Sun, D.; Yamada, Y.; Sato, S.; Ueda, W. Glycerol as a potential renewable raw material for acrylic acid production. Green Chem. 2017, 19, 3186-3213.

(4) Chieregato, A.; Soriano, M.D.; Basile, F.; Liosi, G.; Zamora, S.; Concepcion, P.; Cavani, F. Lopez Nieto, J.M. One-pot glycerol oxydehydration to acrylic acid on multifunctional catalysts: Focus on the influence of the reaction parameters in respect to the catalytic performance. Appl. Catal. B: Environ. 2014, 150-151, 37-46.

(5) Chieregato, A.; Soriano, M.D.; Garcia-Gonzalez, E.; Puglia, G.; Basile, F.; Concepcion, P.; Bandinelli, C.; Lopez Nieto, J.M.; Cavani, F. Multielement Crystalline and Pseudocrystalline Oxides as Efficient Catalysts for the Direct Transformation of Glycerol into Acrylic Acid. ChemSusChem 2015, 8, 398-406.

(6) Fan, Y.; Zhou, C.; Zhu, X. Selective Catalysis of Lactic Acid to Produce Commodity Chemicals, Catal. Rev. 2009, 51, 293-324.

(7) Abdel-Rahman, M.A.; Tashiro, Y.; Sonomoto, K. Lactic acid production from lignocellulosederived sugars using lactic acid bacteria: Overview and limits. BioTech. Adv. 2013, 1, 877-902.

(8) Abdel-Rahman, M.A.; Tashiro, Y.; Sonomoto, K. Recent advances in lactic acid production by microbial fermentation processes. J. Biotech. 2011, 156, 286-301. 
(9) Auneau, F.; SadrArani, L.; Besson, M.; Djakovitch, L.; Michel, C.; Delbecq, F.; Sautet, P.; Pinel, C.; Heterogeneous Transformation of Glycerol to Lactic Acid. Top.Catal. 2012, 55, 474. https://www.businesswire.com/news/home/20170621005594/en/Global-Lactic-AcidMarket-2017-2025---Growth

(11) Blanco, E.; Delichere, P.; Millet, J.M.M.; Loridant, S. Gas phase dehydration of lactic acid to acrylic acid over alkaline-earth phosphates catalysts. Catal. Today, 2014, 226, 185-191.

(12) Blanco, E.; Lorentz, C.; Delichere, P.; Burel, L.; Vrinat, M.; Millet, J.M.M.; Loridant, S. Dehydration of ethyl lactate over alkaline earth phosphates: Performances, effect of water on reaction pathways and active sites, Appl. Catal. B: Environ. 2016, 180, 596-606.

(13) Hammaecher, C.; Paul, J.-F. Density functional theory study of lactic acid adsorption and dehydration reaction on monoclinic $011, \overline{1} 01$, and $\overline{1} 11$ zirconia surfaces. J. Catal. 2013, 300, 174182.

(14) Dorozhkin S.V.; Epple, M. Biological and Medical Significance of Calcium Phosphates, Angew. Chem. Int. Ed. 2002, 41, 3130 - 3146.

(15) Chafik, T.; Dulaurent, O.; Gass, J.L.; Bianchi, D. Heat of Adsorption of Carbon Monoxide on a $\mathrm{Pt} / \mathrm{Rh} / \mathrm{CeO}_{2} / \mathrm{Al}_{2} \mathrm{O}_{3}$ Three-Way Catalyst Using in-Situ Infrared Spectroscopy at High Temperatures. J. Catal. 1998, 179, 503-514.

(16) Giraud, F.; Couble, J.; Geantet, C.; Guilhaume, N.; Puzenat, E.; Gros, S.; Porcheron, L.; Kanniche, M.; Bianchi, D. Experimental Microkinetic Approach of De-NOx by $\mathrm{NH}_{3}$ on $\mathrm{V}_{2} \mathrm{O}_{5} / \mathrm{WO}_{3} / \mathrm{TiO}_{2}$ Catalysts. 4. Individual Heats of Adsorption of Adsorbed $\mathrm{H}_{2} \mathrm{O}$ Species on SulfateFree and Sulfated $\mathrm{TiO}_{2}$ Supports. J. Phys. Chem.C 2015, 119, 16089-16105.

(17) Giraud, F.; Geantet, C.; Guilhaume, N.; Gros, S.; Porcheron, L.; Kanniche, M.; Bianchi, D. Experimental Microkinetic Approach of De-NOx by $\mathrm{NH}_{3}$ on $\mathrm{V}_{2} \mathrm{O}_{5} / \mathrm{WO}_{3} / \mathrm{TiO}_{2}$ Catalysts. 1 . 
Individual Heats of Adsorption of Adsorbed $\mathrm{NH}_{3}$ Species on a Sulfate-Free $\mathrm{TiO}_{2}$ Support Using Adsorption Isobars. J. Phys. Chem. C 2014, 118, 15664-15676.

(18) Giraud, F.; Geantet, C.; Guilhaume, N.; Loridant, S.; Gros, S.; Porcheron, L.; Kanniche, M.; Bianchi, D. Experimental Microkinetic Approach of De-NOx by $\mathrm{NH}_{3}$ on $\mathrm{V}_{2} \mathrm{O}_{5} / \mathrm{WO}_{3} / \mathrm{TiO}_{2}$ Catalysts. 2. Impact of Superficial Sulfate and/or $\mathrm{V}_{\mathrm{x}} \mathrm{O}_{\mathrm{y}}$ groups on the Heats of Adsorption of Adsorbed $\mathrm{NH}_{3}$ Species. J. Phys. Chem. C 2014, 118, 15677-15692.

(19) Giraud, F.; Geantet, C.; Guilhaume, N.; Loridant, S.; Gros, S.; Porcheron, L.; Kanniche, M.;

Bianchi, D. Experimental Microkinetic Approach of De-NOx by $\mathrm{NH}_{3}$ on $\mathrm{V}_{2} \mathrm{O}_{5} / \mathrm{WO}_{3} / \mathrm{TiO}_{2}$ Catalysts. 3. Impact of Superficial $\mathrm{WO}_{\mathrm{z}}$ and $\mathrm{V}_{\mathrm{x}} \mathrm{O}_{\mathrm{y}} / \mathrm{WO}_{\mathrm{z}}$ Groups on the Heats of Adsorption of Adsorbed $\mathrm{NH}_{3}$ Species. J. Phys. Chem. C 2015, 119, 15401-15413.

(20) Buniazet, Z.; Couble, J.; Bianchi, D.; Rivallan, M.; Cabiac, A.; Maury, S.; Loridant, S. Unravelling water effects on solid acid catalysts: Case study of $\mathrm{TiO}_{2} / \mathrm{SiO}_{2}$ as a catalyst for the dehydration of isobutanol, J. Catal. 2017, 348, 125-134.

(21) Kresse, G.; Furthmüller, J. Efficient iterative schemes for ab initio total-energy calculations using a plane-wave basis set. Phys. Rev. B-Condens. Matter Mater. Phys. 1996, 54, 11169-11186. (22) Kresse, G.; Furthmüller, J. Efficiency of ab-initio total energy calculations for metals and semiconductors using a plane-wave basis set. Comput. Mater. Sci. 1996, 6, 15-50.

(23) Kresse, G.; Hafner, J. Ab initio molecular dynamics for liquid metals. Phys. Rev. B - Condens. Matter Mater. Phys. 1993, 47, 558-561.

(24) Perdew, J. P.; Burke, K.; Ernzerhof, M. Generalized Gradient Approximation Made Simple. Phys. Rev. Lett. 1996, 77, 3865-3868.

(25) Kresse, G.; Joubert, D. From ultrasoft pseudopotentials to the projector augmented-wave method. Phys. Rev. B-Condens. Matter Mater. Phys. 1999, 59, 1758-1775. 
(26) Curry, N.A.; Jones, D. W. Crystal Structure of Brushite, Calcium Hydrogen Orthophosphate Dihydrate: A Neutron-diffraction Investigation. J. Chem. Soc. A 1971, 3725-3729.

(27) Hirsch, A., Azuri, I., Addadi, L., Weiner, S., Yang, K., Curtarolo, S., Kronik, L. Infrared Absorption Spectrum of Brushite from First Principles. Chem. Mater. 2014, 26, 2934-2942.

(28) Schofield, P.F.; Knight, K.S.; van der Houwen, J.A.M.; Valsami-Jones, E. The role of hydrogen bonding in the thermal expansion and dehydration of brushite, di-calcium phosphate dihydrate Phys. Chem. Minerals 2004, 31, 606-624.

(29) Kumta, P.N.; Sfeir, C.; Lee, D.-H.; Olton, D.; Choi, D. Nanostructured calcium phosphates for biomedical applications: novel synthesis and characterization, Acta Biomaterialia, 2005, 1, 6583.

(30) Baroni, S.; Giannozzi, P.; Testa, A. Green's-Function Approach to Linear Response in Solids. Phys. Rev. Lett. 1987, 58, 1861-1894.

(31) Bauer, T.; Maisel, S.; Blaumeiser, D.; Vecchietti, J.; Taccardi, N.; Wasserscheid, P.; Bonivardi, A.; Görling, A.; Libuda, J. ACS Catal. 2019, 9, 2842-2853.

(32) Anggara, T.; Paolucci, C.; Schneider, W.F. J. Phys. Chem. C 2016, 120, 27934-27943.

(33) Chizallet, C.; Costentin, G. ; Che, M. ; Delbecq, F. ; Sautet, P. J. Am. Chem. Soc. 2007, 129, 6442-6452.

(34) Cheng, Z.H.; Yasukawa, A.; Kandori, K.; Ishikawa, T. FTIR Study on incorporation of $\mathrm{CO}_{2}$ into calcium hydroxyapatite. J. Chem. Soc., Faraday Trans. 1998, 94, 1501-1505.

(35) Trchova, M.; Capkova, P.; Matejka, P.; Melanova, K.; Benes, L. Study of Host-Guest Interactions in Intercalate $\mathrm{Zr}\left(\mathrm{HPO}_{4}\right)_{2} \cdot 2 \mathrm{CH}_{3} \mathrm{CH}_{2} \mathrm{OH}$ using a Combination of Vibration Spectroscopy and Molecular Simulations. J. Solid State Chem. 1999, 145, 1-9.

(36) Koleva, V.; Stefov, V.; Cahil, A.; Najdoski, M.; Soptrajanov, B.; Engelen, B.; Lutz, H.D. 
Infrared and Raman studies of manganese dihydrogen phosphate dihydrate, $\mathrm{Mn}\left(\mathrm{H}_{2} \mathrm{PO}_{4}\right)_{2} .2 \mathrm{H}_{2} \mathrm{O}$. Part II: Region of the internal OH group vibrations. J. Mol. Struct. 2009, 919, 164-169.

(37) Frost, R.L.; Xi, Y.; Palmer, S.J.; Tan, K. Millar, G.J. Vibrational spectroscopy of synthetic archerite $\left(\mathrm{K}, \mathrm{NH}_{4}\right) \mathrm{H}_{2} \mathrm{PO}_{4}^{-}$and in comparison with the natural cave mineral. J. Mol. Struct. 2012, $1011,128-133$.

(38) Frost, R.L.; Palmer, S.J.; Xi, Y. A Raman spectroscopic study of the mono-hydrogen phosphate mineral dorfmanite $\mathrm{Na}_{2}\left(\mathrm{PO}_{3} \mathrm{OH}\right) \cdot 2 \mathrm{H}_{2} \mathrm{O}$ and in comparison with brushite. Spectrochim. Acta Part A 2011, 82, 132-136.

(39) Giraud, F.; Couble, J.; Geantet, C.; Guilhaume, N.; Puzenat, E.; Gros, S.; Porcheron, L.; Kanniche, M.; Bianchi, D. Experimental Microkinetic Approach of De-NOx by $\mathrm{NH}_{3}$ on $\mathrm{V}_{2} \mathrm{O}_{5} / \mathrm{WO}_{3} / \mathrm{TiO}_{2}$ Catalysts. 4. Individual Heats of Adsorption of Adsorbed $\mathrm{H}_{2} \mathrm{O}$ Species on SulfateFree and Sulfated $\mathrm{TiO}_{2}$ Supports. J. Phys. Chem. C 2015, 119, 16089-16105.

(40) Buniazet, Z.; A. Cabiac, S. Maury, D. Bianchi, S. Loridant, Unexpected selectivity of ferrierite for the conversion of isobutanol to linear butenes and water effects, Appl. Catal. B: Environmental 2019, 243, 594-603.

(41) Dosen, A.; Giese, R.F. Thermal decomposition of brushite, $\mathrm{CaHPO}_{4} \cdot 2 \mathrm{H}_{2} \mathrm{O}$ to monetite $\mathrm{CaHPO}_{4}$ and the formation of an amorphous phase, American Mineralogist, 2011, 96, 368-373. (42) Lagno, F.;. Rocha, S.D.F; Katsarou, L.; Demopoulos, G.P. Supersaturation-Controlled Synthesis of Dicalcium Phosphate Dihydrate and Nanocrystalline Calcium-Deficient Hydroxyapatite, Ind. Eng. Chem. Res. 2012, 51, 6605-6612.

(43) Wang, L.; Nancollas, G.H. Calcium Orthophosphates: Crystallization and Dissolution, Chem. Rev. 2008, 108, 4628-4669.

(44) Busca, G. The surface acidity of solid oxides and its characterization by IR spectroscopic 
methods. An attempt at systematization Phys. Chem. Chem. Phys. 1999, 1, 723-736.

(45) Busca, G. Spectroscopic characterization of the acid properties of metal oxide catalysts. Catal. Today 1998, 41, 191-206.

(46) Oliviero, L.; Vimont, A.; Lavalley, J.-C.; Romero Sarria, F.; Gaillard, M.; Mauge, F. 2,6Dimethylpyridine as a probe of the strength of Brønsted acid sites: study on zeolites. Application to alumina. Phys. Chem.Chem. Phys. 2005, 7, 1861-1869.

(47) Onfroy, T.; Clet, G.; Houalla, M. Quantitative IR characterization of the acidity of various oxide catalysts. Micropor.Mesopor. Mater. 2005, 82, 99-104.

(48) Giraud, F.; Geantet, C.; Guilhaume, N.; Loridant, S.; Gros, S.; Porcheron, L.; Kanniche, M.; Bianchi, D. Experimental Microkinetic Approach of De-NOx by $\mathrm{NH}_{3}$ on $\mathrm{V}_{2} \mathrm{O}_{5} / \mathrm{WO}_{3} / \mathrm{TiO}_{2}$ Catalysts. 1. Individual Heats of Adsorption of Adsorbed $\mathrm{NH}_{3}$ Species on a Sulfate-Free $\mathrm{TiO}_{2}$ Support Using Adsorption Isobars. J. Phys. Chem. C 2014, 118, 15677-15692.

(49) Zecchina, A.; Marchese, L.; Bordiga, S.; Pazè, C.; Gianotti, E. Vibrational Spectroscopy of $\mathrm{NH}_{4}{ }^{+}$Ions in Zeolitic Materials: An IR Study. J. Phys. Chem. B 1997, 101, 10128-10135.

(50) Plaza, I.; Rubin, J.; Laguna, M.A.; Bartolomé, J. Optical spectroscopy of the $\mathrm{NH}_{4}{ }^{+}$internal vibrations in the orthorhombic phase of $\mathrm{NH}_{4} \mathrm{MF}_{3}$ (M is Mn, $\mathrm{Zn}$ ) perovskites. Spectrochimica Acta Part A 1996, 52, 57-67. 


\section{FIGURES CAPTIONS}

Figure 1: In situ DRIFT spectra of $\mathrm{BaOP}$ at $380{ }^{\circ} \mathrm{C}$ under $\mathrm{He}, 30 \% \mathrm{H}_{2} \mathrm{O}-\mathrm{He}$ and $30 \% \mathrm{D}_{2} \mathrm{O}-\mathrm{He}$. The background corresponds to the spectrum of dehydrated $\mathrm{KBr}$.

Figure 2: Unit cell of the layered structure of the Brushite, containing $\mathrm{Ca}$ atoms (grey), $\mathrm{O}$ atoms (red), $\mathrm{H}$ atoms (yellow) and $\mathrm{P}$ atoms (green).

Figure 3: Structures of the (010) surface of $\mathrm{CaHPO}_{4} \cdot \mathrm{nH}_{2} \mathrm{O}$ with different water coverages, $\theta$ $\left(\mathrm{H}_{2} \mathrm{O}\right)=1 \mathrm{ML}, 7 / 8 \mathrm{ML}, 1 / 8 \mathrm{ML}$ and $0 \mathrm{ML}$. Only half of the surface structure is shown here for simplicity. The two different types of water molecules are marked as $\mathrm{W}_{\mathrm{a}}$ and $\mathrm{W}_{\mathrm{b}}$ highlighted by a black circle in the top left structure, which corresponds to the structure obtained as cleaved from the bulk. The $\mathrm{H}$ bond network of $\mathrm{W}_{\mathrm{a}}$ and $\mathrm{W}_{\mathrm{b}}$ is shown in light blue dashed lines. At $1 \mathrm{ML}, 8$ water molecules are found. At 7/8ML, one $\mathrm{W}_{\mathrm{b}}$ water has been removed and the black circle indicates its former position. At 1/8ML, only one water molecule remains ( $\mathrm{W}_{\mathrm{a}}$ type $)$ as highlighted by a black circle. Color-coding: grey for calcium, red for oxygen, green for phosphorus and yellow for hydrogen.

Figure 4: Surface energy in $\mathrm{eV} / \AA^{2}$ of Brushite $(010)$ surfaces with various coverages $\left(\theta\left(\mathrm{H}_{2} \mathrm{O}\right)=1\right.$ ML, 7/8 ML, 1/8 ML and $0 \mathrm{ML}$ ) in water as function of the temperature and under a pressure in water of $1 \mathrm{~atm}$.

Figure 5: Computed structure of the defective surface. The $\mathrm{Ca}^{2+}$ vacancy is shown with a blue circle, the $\mathrm{H}_{\text {down }}$ with a pink dashed circle and $\mathrm{H}_{\text {up }}$ with a pink solid circle. The calculated wavenumbers (after rescaling as mentioned in the 2.3 section) of $v(\mathrm{PO}-\mathrm{H})$ vibrations on the first layer are also shown nearby in $\mathrm{cm}^{-1}$. Color-coding: grey for calcium, red for oxygen, green for phosphorus and yellow for hydrogen, except surface Hup, which is marked in white. 
Figure 6: Evolution of the FTIR spectra of $\mathrm{BaOP}$ after adsorption of lutidine and desorption under vacuum at increasing temperature.

Figure 7: Evolution of the IR bands of $\mathrm{NH}_{3}$ adsorbed species on pre-treated BaOP catalyst recorded under $2 \% \mathrm{NH}_{3}$-He flow from 120 to $7{ }^{\circ} \mathrm{C}$. The backgrounds correspond to the spectra recorded after pretreatment under He flow at the same temperatures, mass of the pellet $53 \mathrm{mg}$.

Figure 8: Structures (top view) and computed wavenumbers (in $\left.\mathrm{cm}^{-1}\right)$ of the $v(\mathrm{PO}-\mathrm{H})$ stretching vibrations and of the $\mathrm{NH}_{3}$ or $\mathrm{NH}_{4}^{+}$vibrations after the adsorption of $\mathrm{NH}_{3}$ on the non-defective dehydrated surface $(A$ and $B)$ and on the defective surface $(C$ and $D)$ at a coverage of $\theta\left(\mathrm{NH}_{3}\right)=1 / 4$ ML. The corresponding adsorption energies are reported in Table 2. Color-coding: grey for calcium, red for oxygen, green for phosphorus, blue for nitrogen and yellow for hydrogen, except surface $\mathrm{H}_{\mathrm{up}}$, which is marked in white.

Figure 9: Evolution of the IR bands of $\mathrm{NH}_{3}$ adsorbed species on pre-treated BaOP catalyst recorded under $1 \% \mathrm{NH}_{3}-3 \% \mathrm{H}_{2} \mathrm{O}-\mathrm{He}$ flow from 172 to $28{ }^{\circ} \mathrm{C}$. The backgrounds correspond to the spectra recorded after pretreatment under He flow at the same temperatures, mass of the pellet 53 mg.

Figure 10: Structures and computed wavenumbers (in $\mathrm{cm}-1)$ of the $v(\mathrm{PO}-\mathrm{H})$ stretching vibrations, water vibration and of the $\mathrm{NH}_{3}$ or $\mathrm{NH}_{4}{ }^{+}$vibration after the adsorption of $\mathrm{NH}_{3}$ on the non-defective dehydrated surface (E and $F$ ) and on the defective surface $(G)$. The corresponding adsorption energies are reported in Table 2. Color-coding: grey for calcium, red for oxygen, green for phosphorus, blue for nitrogen and yellow for hydrogen, except surface $\mathrm{H}_{\mathrm{up}}$, which is marked in white. 


\title{
TABLES CAPTIONS
}

Table 1: Influence of the PO-H orientation in the non-defective dehydrated (010) surface of Brushite on the stability at $380{ }^{\circ} \mathrm{C}$ and the computed wavenumbers of $v(\mathrm{PO}-\mathrm{H})$, reported after rescaling as mentioned in the 2.3 section.

\begin{abstract}
Table 2: Adsorption energy of water and ammonia on the non-defective and defective surface corresponding to the structures shown in Figure 8 and Figure 10. The adsorption of ammonia is given as a successive adsorption after the adsorption of water on structures E, F and G.
\end{abstract}




\section{TOC Graphic}

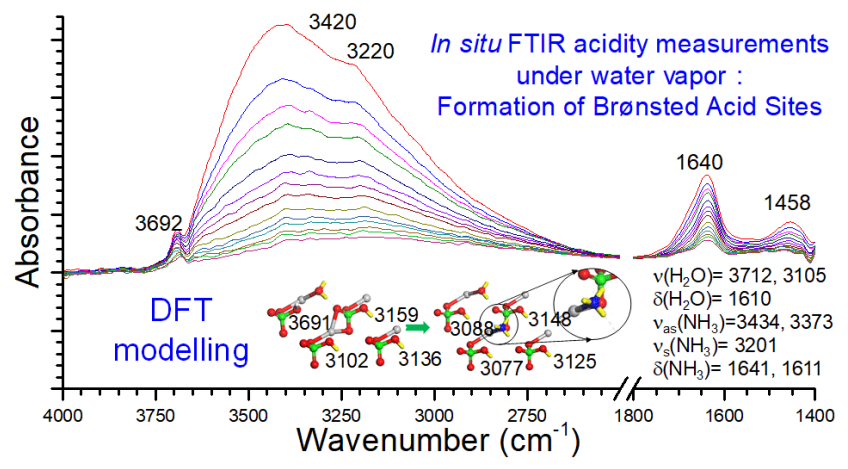




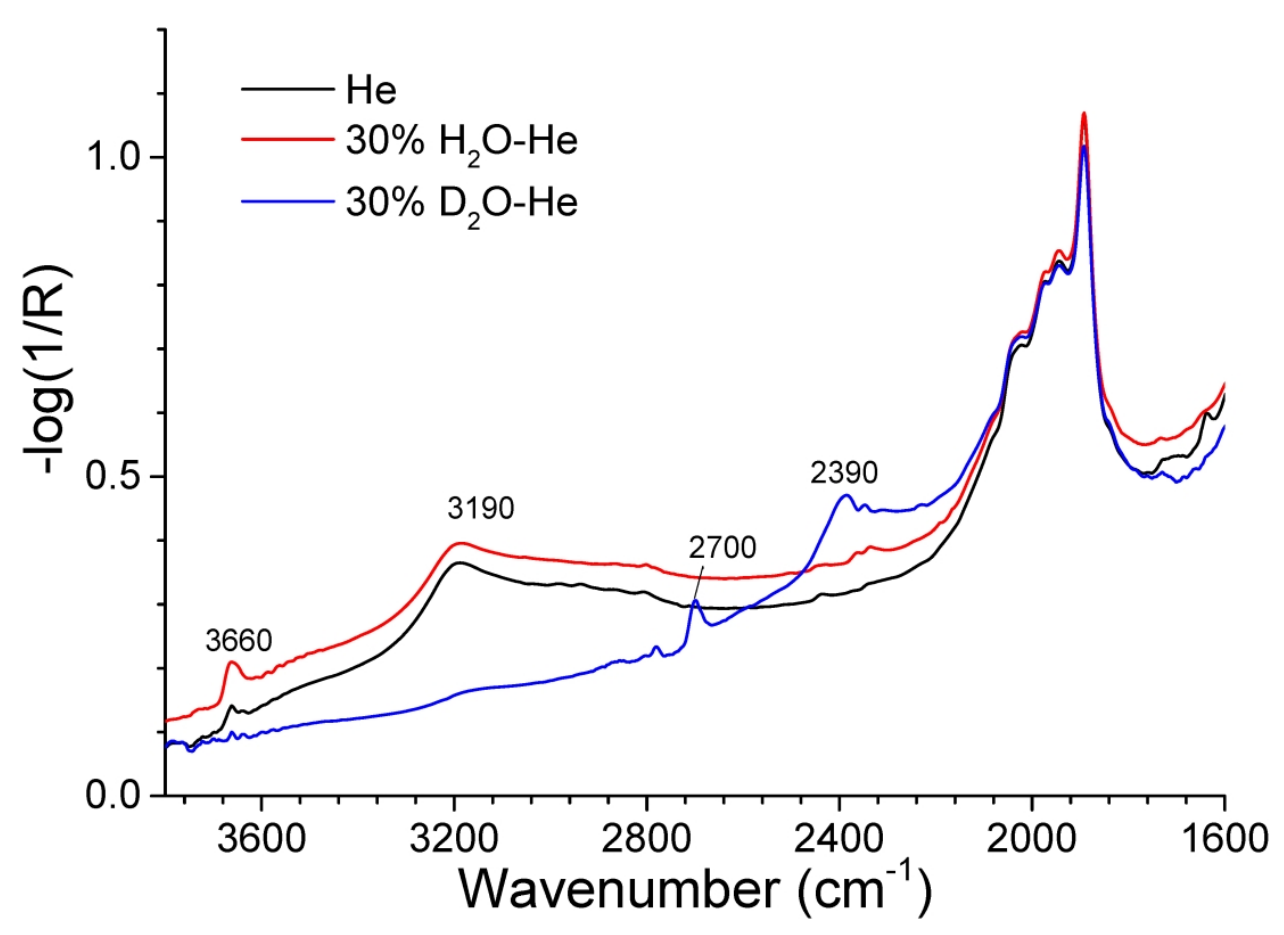

Figure1

$297 \times 210 \mathrm{~mm}(300 \times 300 \mathrm{DPI})$ 


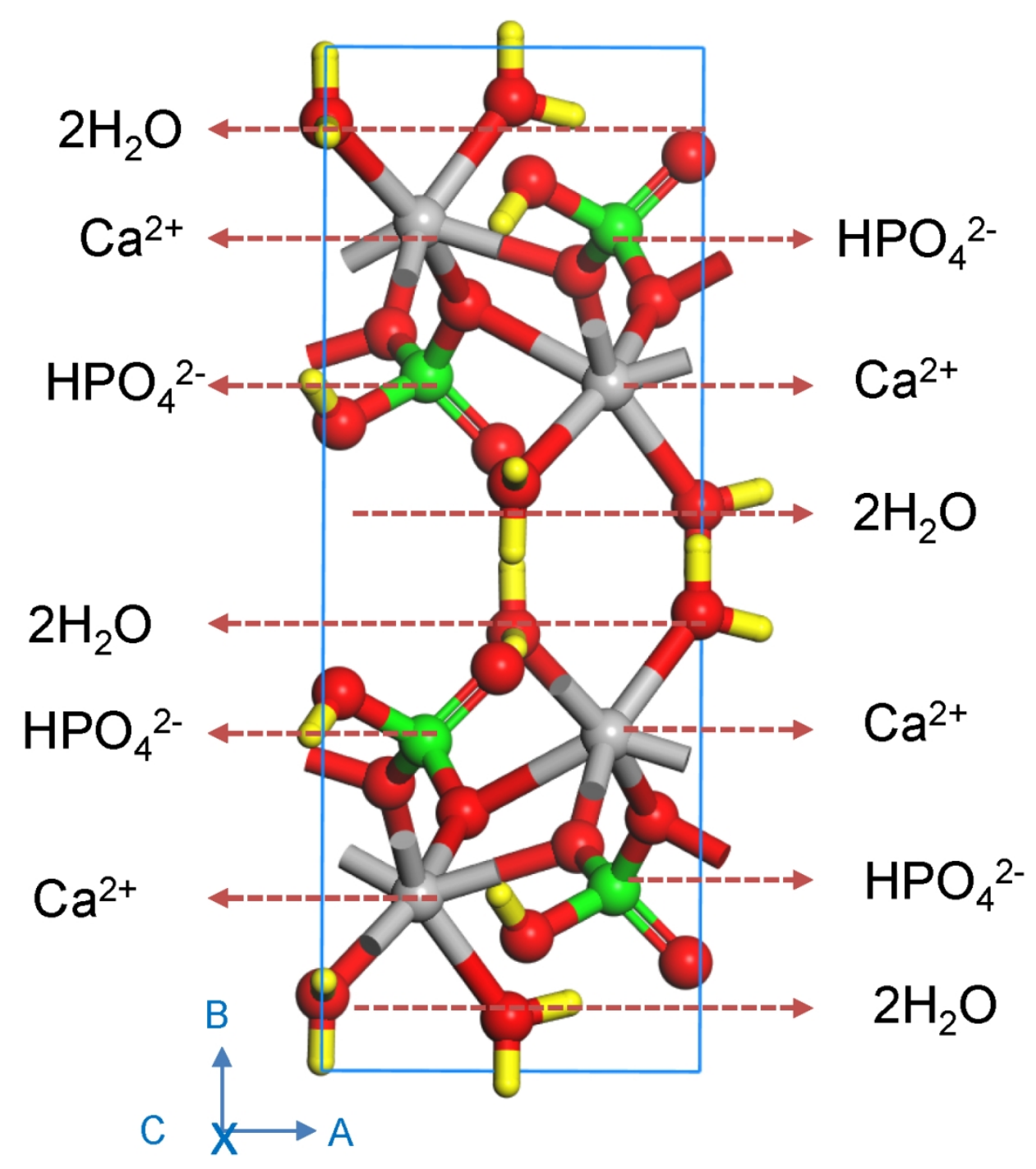

Figure2

$117 \times 132 \mathrm{~mm}(300 \times 300 \mathrm{DPI})$ 


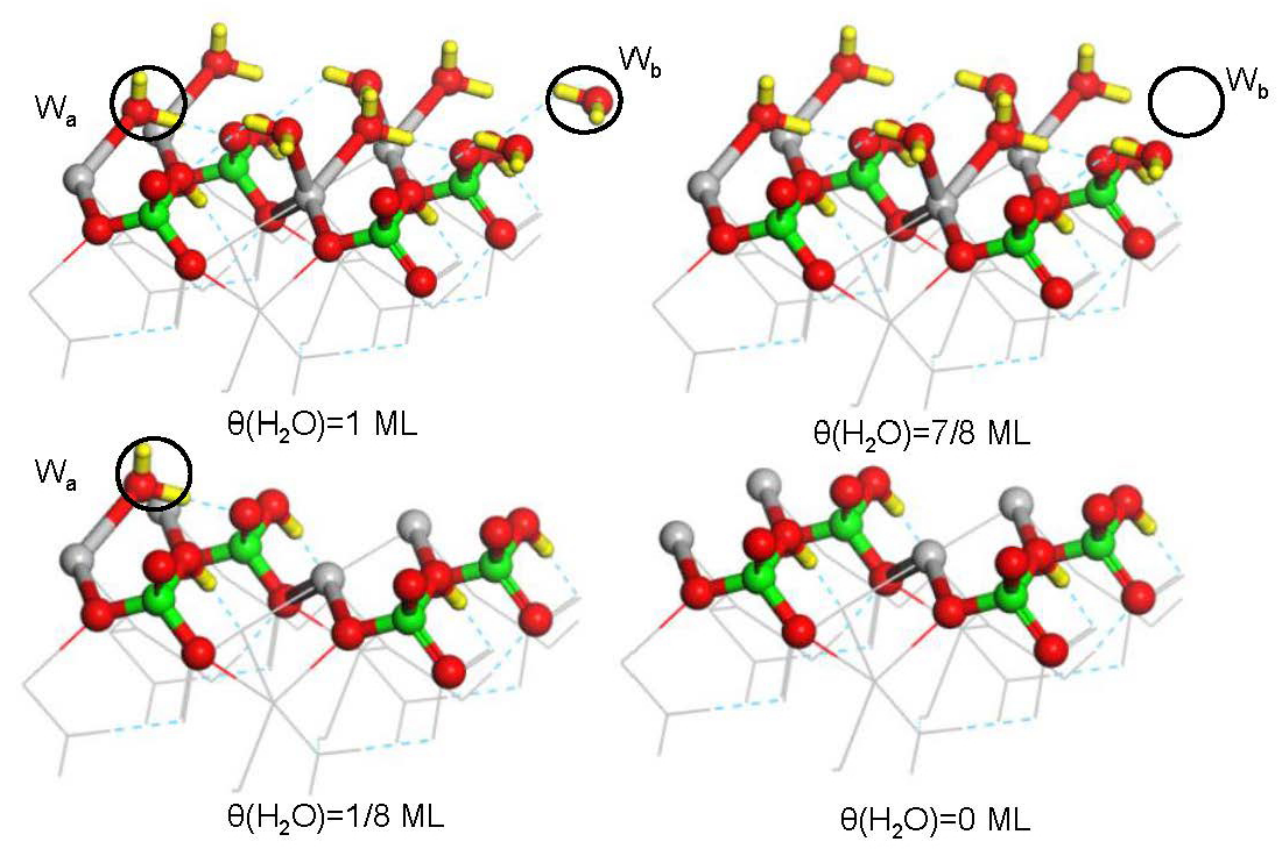

Figure 3

$199 \times 132 \mathrm{~mm}(142 \times 142 \mathrm{DPI})$ 


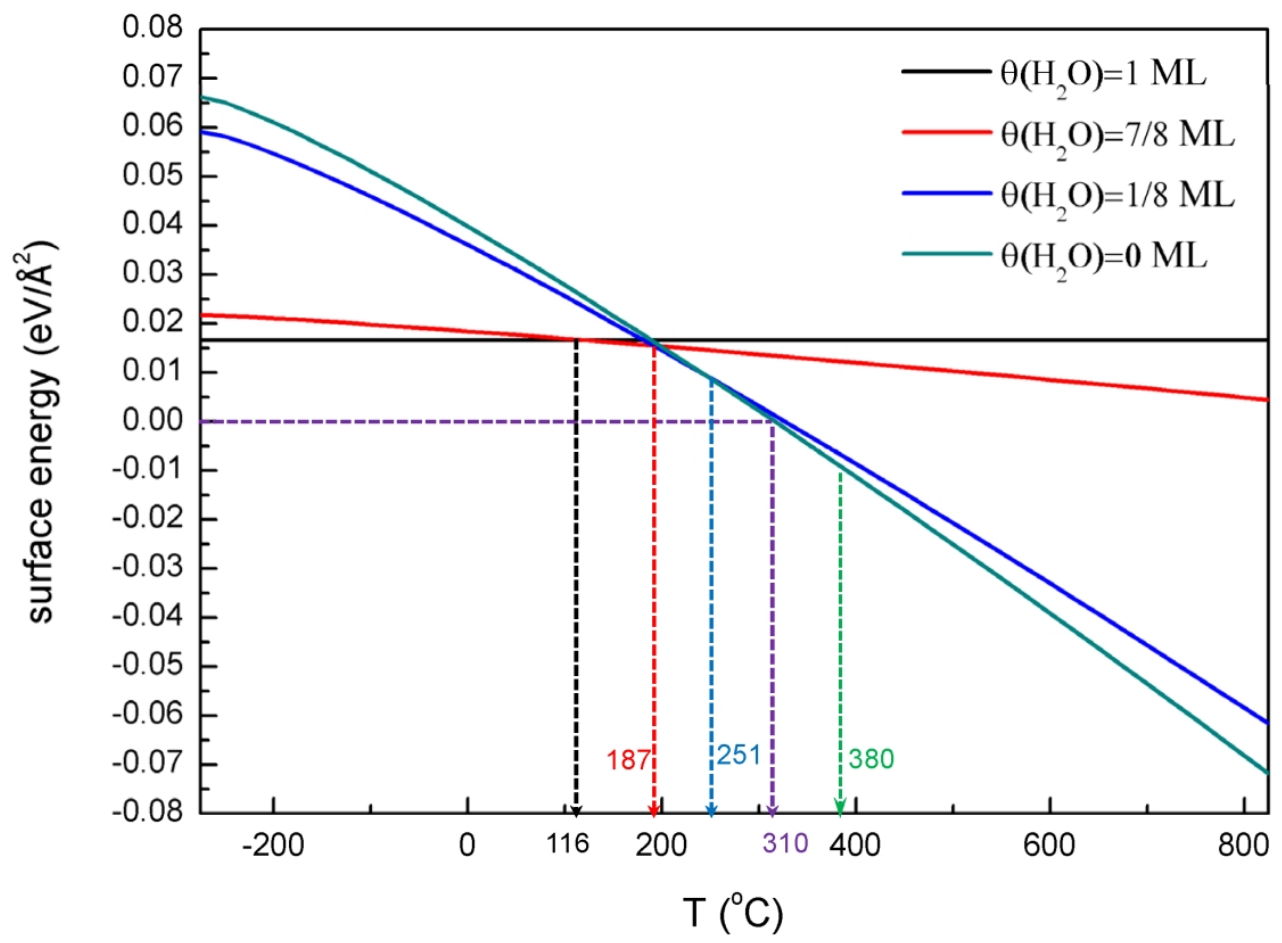

Figure4

$226 \times 165 \mathrm{~mm}(300 \times 300$ DPI $)$ 


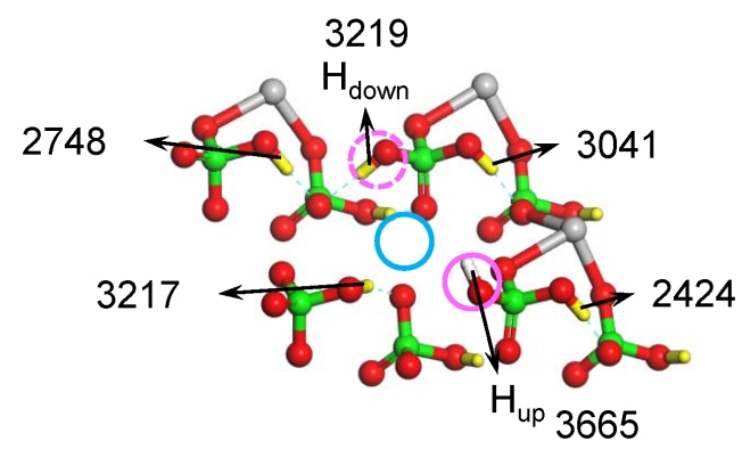

Top view

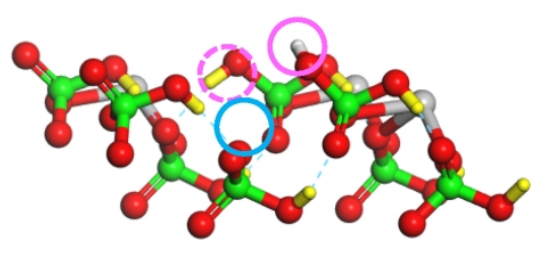

Side view

Figure5

$192 \times 78 \mathrm{~mm}(300 \times 300$ DPI) 


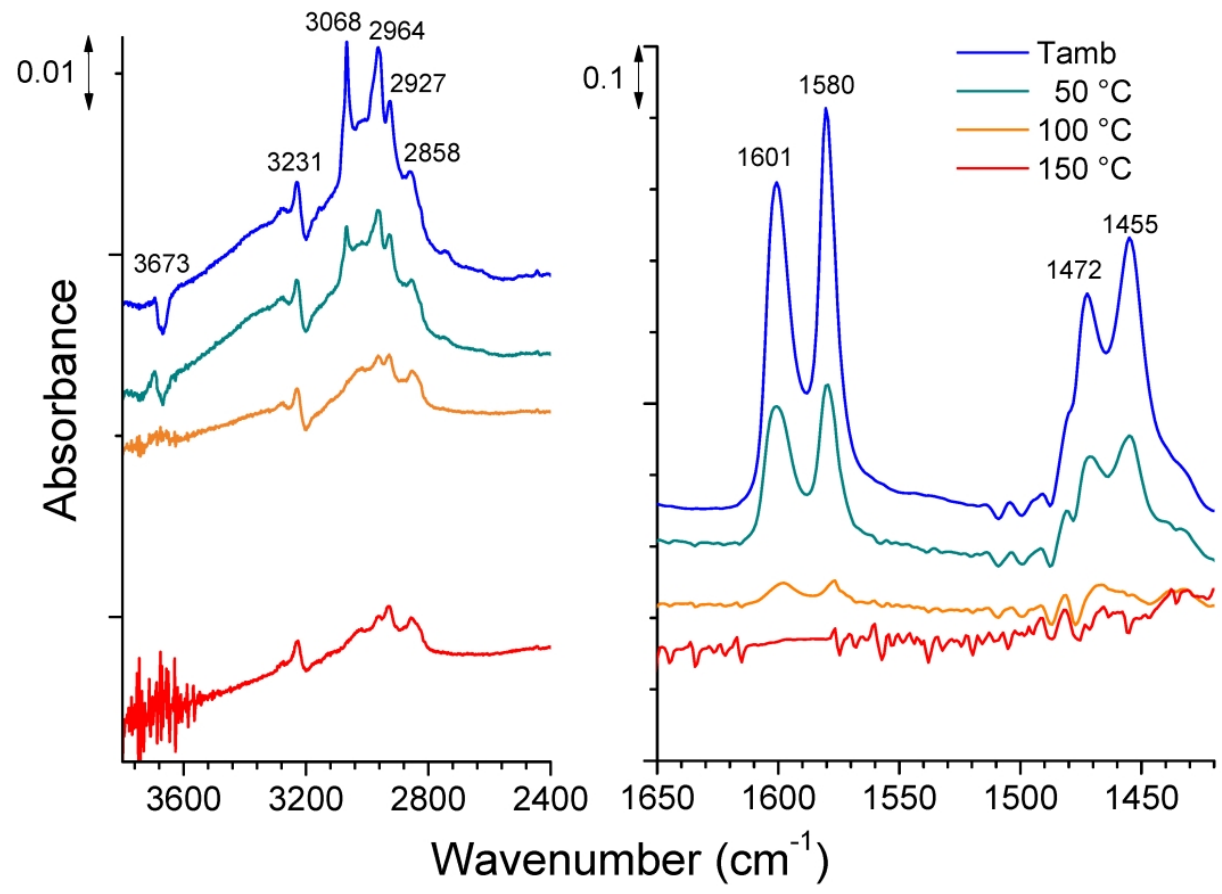

Figure6

$297 \times 210 \mathrm{~mm}(300 \times 300$ DPI $)$ 


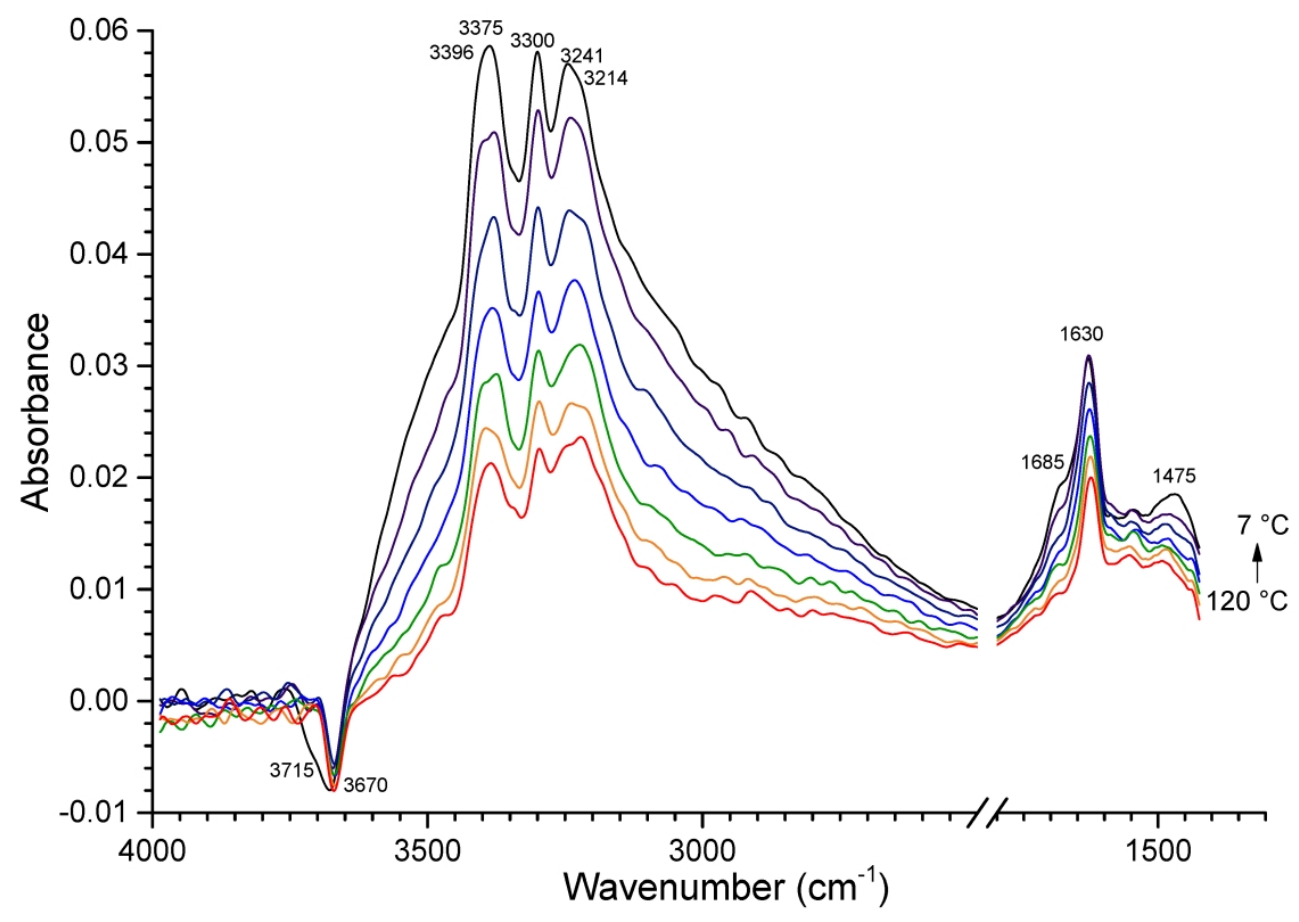

Figure7

$297 \times 210 \mathrm{~mm}(300 \times 300$ DPI) 


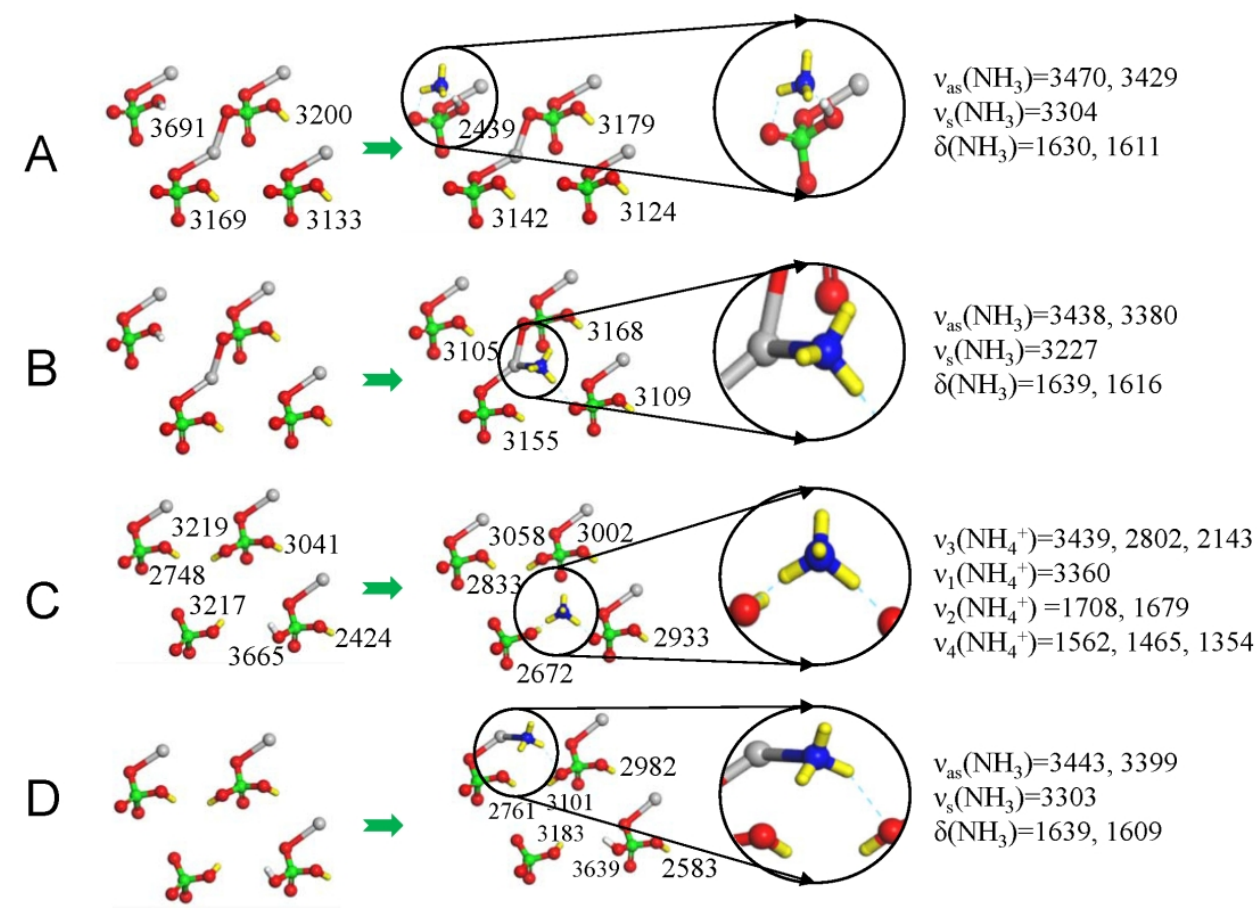

Figure8

$191 \times 135 \mathrm{~mm}(300 \times 300$ DPI $)$ 


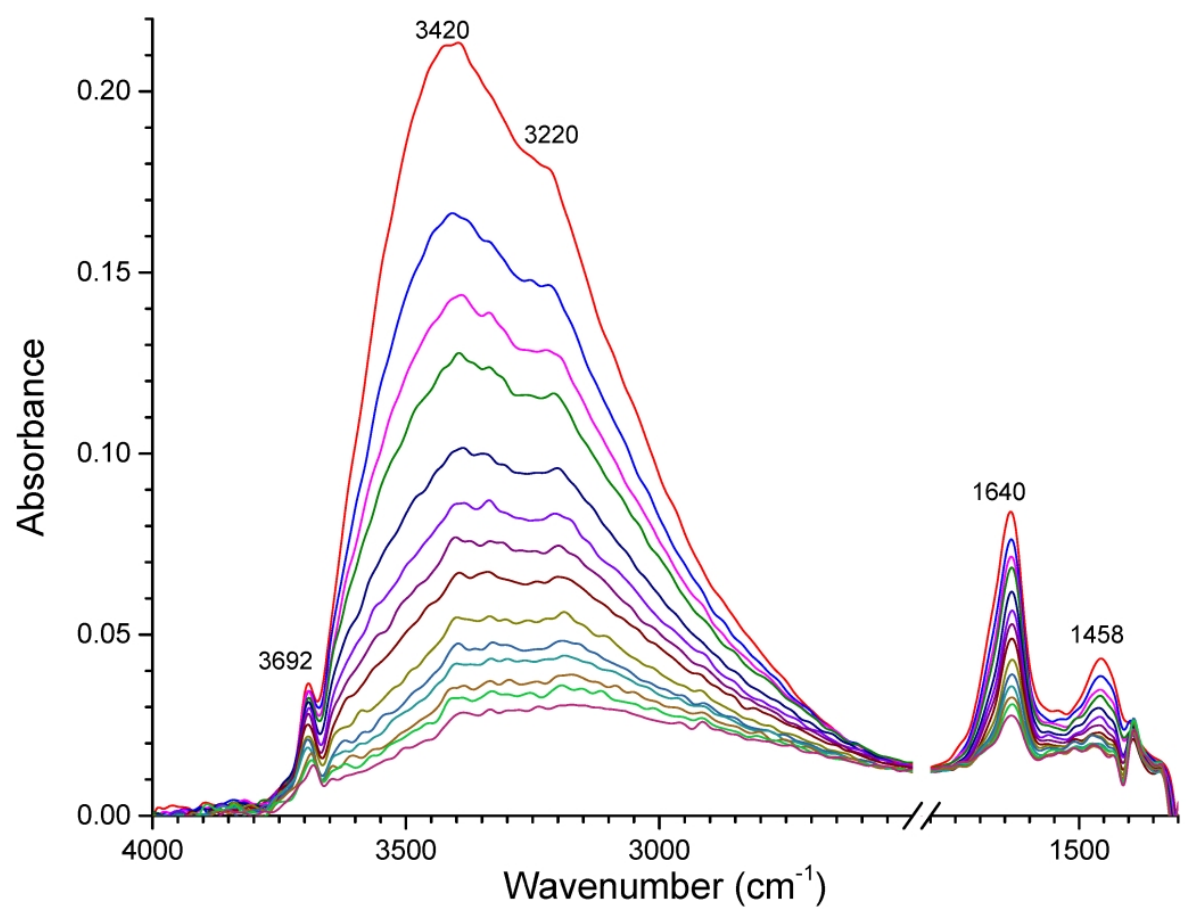

Figure9

$297 \times 210 \mathrm{~mm}(300 \times 300$ DPI $)$ 


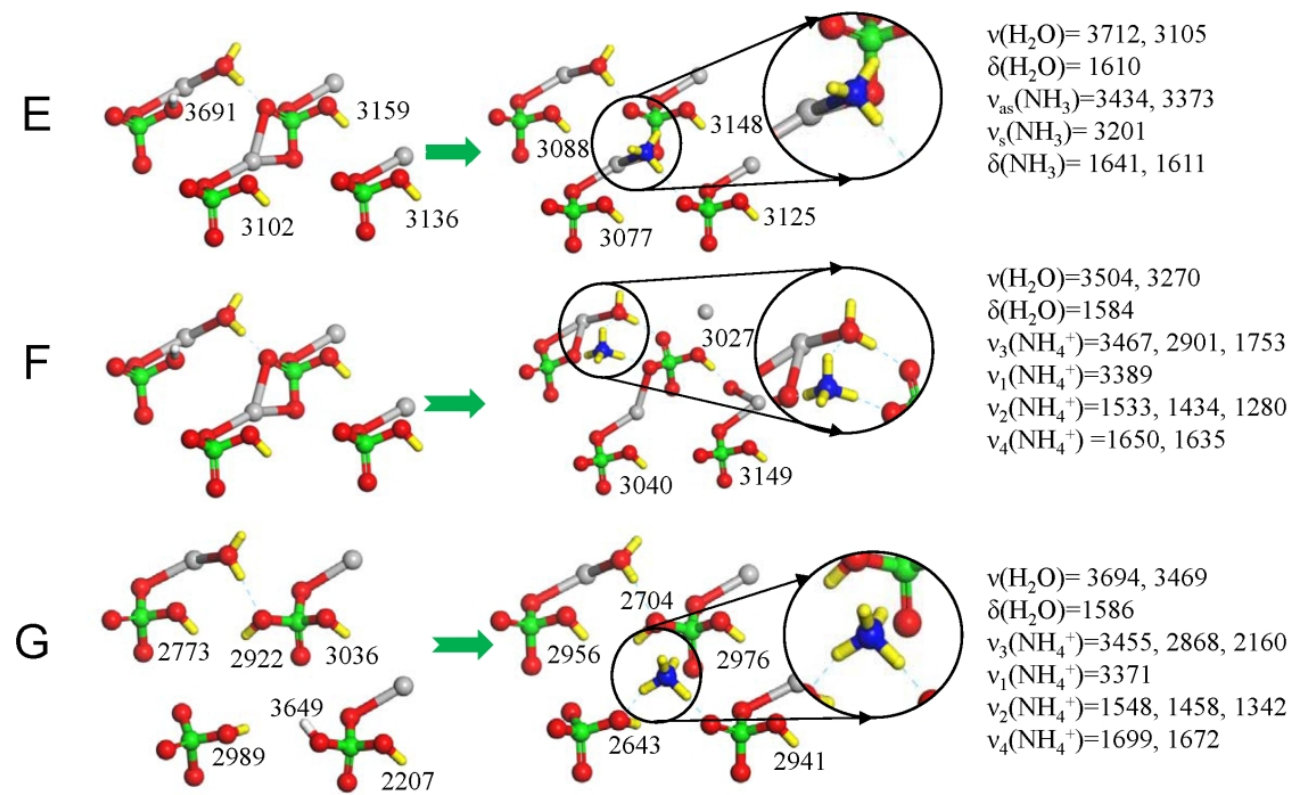

Figure10

204x129mm (300 x 300 DPI) 


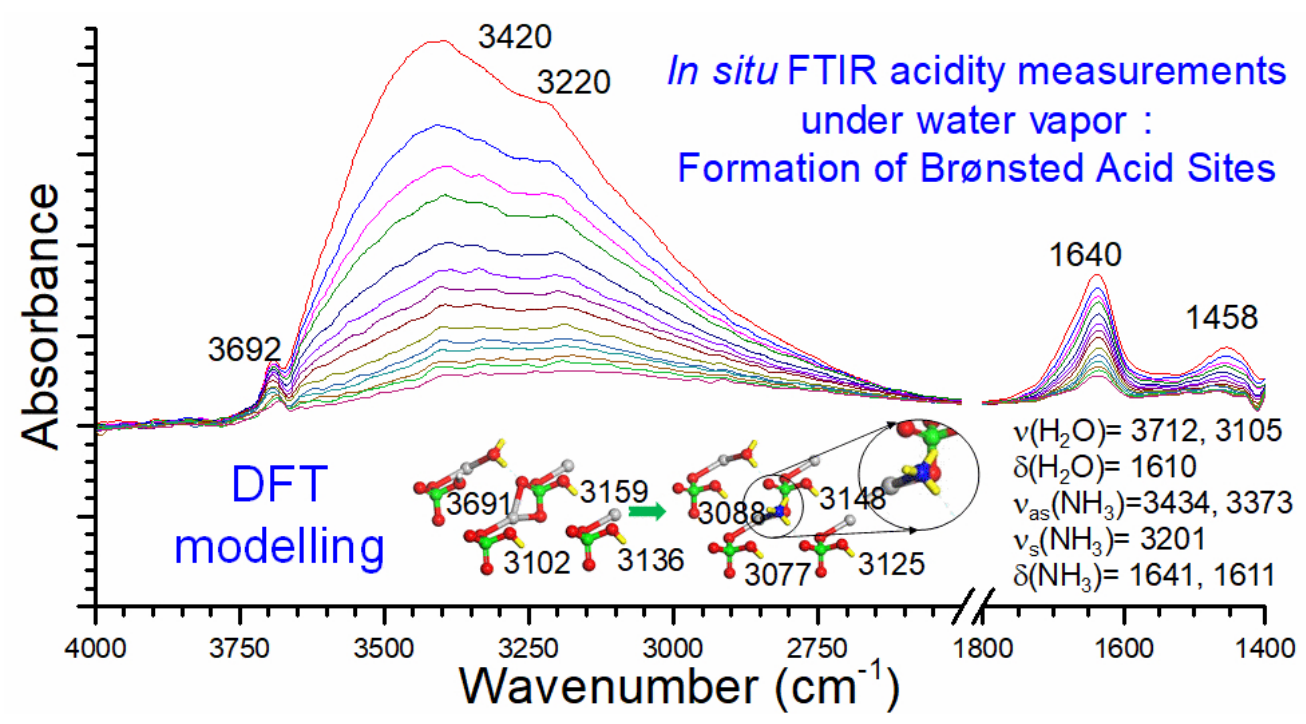

TOC Graphic

$82 \times 44 \mathrm{~mm}(300 \times 300$ DPI $)$ 